\title{
Blocking epithelial-to-mesenchymal transition in glioblastoma with a sextet of repurposed drugs: the EIS regimen
}

\author{
Richard E. Kast ${ }^{1}$, Nicolas Skuli ${ }^{2}$, Georg Karpel-Massler ${ }^{3}$, Guido Frosina ${ }^{4}$, Timothy \\ Ryken $^{5}$ and Marc-Eric Halatsch ${ }^{3}$ \\ ${ }^{1}$ IIAIGC Study Center, Burlington, VT, USA \\ 2 INSERM, Centre de Recherches en Cancérologie de Toulouse, CRCT, Inserm/Université Toulouse III, Paul Sabatier, Hubert \\ Curien, Toulouse, France \\ ${ }^{3}$ Department of Neurosurgery, UIm University Hospital, Albert-Einstein-Allee, Ulm, Germany \\ ${ }^{4}$ Mutagenesis \& Cancer Prevention Unit, IRCCS Azienda Ospedaliera Universitaria San Martino, IST Istituto Nazionale per la \\ Ricerca sul Cancro, Largo Rosanna Benzi, Genoa, Italy \\ ${ }^{5}$ Department of Neurosurgery, University of Kansas, Lawrence, KS, USA \\ Correspondence to: Richard E. Kast, email: richarderickast@gmail.com
}

Keywords: AMPK, EIS regimen, EMT, glioma, glioblastoma

Received: March 02, $2017 \quad$ Accepted: May 12, 2017

Published: June 01, 2017

Copyright: Kast et al. This is an open-access article distributed under the terms of the Creative Commons Attribution License 3.0 (CC BY 3.0), which permits unrestricted use, distribution, and reproduction in any medium, provided the original author and source are credited.

\section{ABSTRACT}

This paper outlines a treatment protocol to run alongside of standard current treatment of glioblastoma- resection, temozolomide and radiation. The epithelial to mesenchymal transition (EMT) inhibiting sextet, EIS Regimen, uses the ancillary attributes of six older medicines to impede EMT during glioblastoma. EMT is an actively motile, therapy-resisting, low proliferation, transient state that is an integral feature of cancers' lethality generally and of glioblastoma specifically. It is believed to be during the EMT state that glioblastoma's centrifugal migration occurs. EMT is also a feature of untreated glioblastoma but is enhanced by chemotherapy, by radiation and by surgical trauma. EIS Regimen uses the antifungal drug itraconazole to block Hedgehog signaling, the antidiabetes drug metformin to block AMP kinase (AMPK), the analgesic drug naproxen to block Rac1, the anti-fibrosis drug pirfenidone to block transforming growth factor-beta (TGF-beta), the psychiatric drug quetiapine to block receptor activator NFkB ligand (RANKL) and the antibiotic rifampin to block Wntall by their previously established ancillary attributes. All these systems have been identified as triggers of EMT and worthy targets to inhibit. The EIS Regimen drugs have a good safety profile when used individually. They are not expected to have any new side effects when combined. Further studies of the EIS Regimen are needed.

\section{INTRODUCTION}

Epithelial to mesenchymal transition (EMT) refers to a transient process where flat, sessile, mutually adherent epithelioid cells take on a rounded, non-adherent, motile mesenchymal shape and behavior [1-4]. EMT is engaged by normal cells during wound healing and is identified in cancer generally. The reverse, less transient state and process, mesenchymal to epithelial transition (MET), also occurs. Both processes are features of robust or aggressive cancer growth [5]. Cells post-EMT tend to be invasive but proliferation-restricted. Cells post MET tend to be proliferative but have limited invasiveness [1-4]. Table 1 lists some of the surface markers and cell characteristics commonly used to define, and are associated with, the two phenotypic states. EMT has been demonstrated in and is central to glioblastoma (GB) pathology [6]. In a landmark immunohistochemical study looking at paired primary and recurrent GB, Kubelt et al showed high expression of vimentin, TGF-beta, beta-catenin and fibronectin- all EMT markers- in both primary tumor and in recurrence tissues [6].

In this paper we propose a combination of 6 repurposed, already-marketed drugs in order to inhibit 
Table 1: Some of the biochemical marker and phenotypic changes characteristic of and concomitant to transformation of a cancer cell from epithelial to a mesenchymal phenotype.

\begin{tabular}{|l|l|l|}
\hline marker / mediator & epithelial state & mesenchymal state \\
\hline E-cadherin & increased & decreased \\
\hline N-cadherin & decreased & increased \\
\hline ZO-1 & increased & decreased \\
\hline occludin & increased & increased \\
\hline vimentin & decreased & increased \\
\hline fibronectin & decreased & increased \\
\hline MMP-2 & decreased & increased \\
\hline MMP-9 & decreased & mesenchymal state \\
\hline phenotype & epithelial state & motile \\
\hline motility & sessile & rounded \\
\hline shape & elongated & non-adherent to neighbors \\
\hline adherence & adherent to neighbors & invasive \\
\hline invasion & non-invasive & low \\
\hline proliferation & high & present * \\
\hline microtentacles & absent & \\
\hline
\end{tabular}

EMT during primary treatment of GB. As we will show, this EMT inhibiting sextet, the EIS Regimen, is predicted to be safe and carry low risk of side effects. The EIS Regimen uses ancillary attributes of older, alreadymarketed drugs to block individual elements of EMT triggered by our current standard treatment of GB. EIS uses the antifungal drug itraconazole to block Hedgehog signaling $(\mathrm{Hh})$, the antidiabetes drug metformin to block AMP kinase (AMPK), the analgesic drug naproxen to block Rac1, the anti-fibrosis drug pirfenidone to block transforming growth factor-beta (TGF-beta), the psychiatric drug quetiapine to block receptor activator NFkB ligand, (RANKL) and the antibiotic rifampin (also called rifampicin) to block beta-catenin nuclear functionsall by their previously established ancillary attributes. Hh, AMPK, Rac1, TGF-beta, RANKL, and beta-catenin have all been identified as triggers to EMT. There doesn't seem to be a single path to EMT development. The multiple triggers initiating EMT that are discussed in this paper might have a common denominator but such hasn't been recognized yet and may not exist.

Glioma initiating cells (GIC, also called glioma stem cells) is an evolving concept that refers to minor subpopulations within a tumor that i] are relatively quiescent, ii] are relatively resistant to cytotoxic chemoand radiotherapies compared to the bulk population, iii] are the residual post-treatment populations from which recurrent tumor regrows, iv] that need fewer cells to establish xenograft growth compared to the bulk population, and v] display in some cases ability to undergo asymmetric cell division where one daughter cell retains stem cell characteristics, the other daughter cell has characteristics of the non-stem majority population.
Concepts and definitions of EMT, as for concepts of GIC, are both in evolution and defined in general outline only [7-11]. Intermediate and mixed forms are recognized but without assuming strictly dichotomous categories, the GIC subpopulation tends to reside in cells with more mesenchymal post-EMT attributes [7, 12, 13]. Some evidences also show that GIC present high expression of EMT markers involved in migration and invasion, such as the matrix metalloproteinases (MMP), particularly MMP-2 and MMP-9 [14, 15]. This enrichment in proinvasive/migratory genes confers GIC stronger invasive and infiltrative capacities. Both EMT and GIC may be reversible processes. Mesenchymal transformed cells revert to an epithelial form and marker status, (undergo MET) whilst non-GIC cells can assume cancer initiating properties and gain relevant markers. (Note that abbreviation MET also can refer to the unrelated cMET, the cell surface receptor for hepatic growth factor). These different GIC coexist within the same tumor and can switch from one invasive state (mesenchymal) to a proliferative one (epithelial) to allow tumor expansion and growth [16].

The growth enhancing role of EMT in GB has been thoroughly reviewed in 2016 by Iser et al [17]. The development of detyrosinated alpha-tubulin microtentacles occurring during EMT facilitates tumor cell insinuation between endothelial cells, starting tumor cell journey to distant metastasis sites [18] or in the case of GB, migratory spreading within the brain [19]. Through a variety of mechanisms, among which reduced proliferation may play a major role, EMT makes cancer cells more resistant to our traditional, currently available, cytotoxic chemotherapy [20]. Entering EMT is a major resistance mechanism for 
GB resistance to erlotinib [21] for example. Importantly, circulating tumor cells from which metastases are derived, are mostly cells that have undergone EMT [22-24].

Table 1. lists the protein expressions and behavioral attributes associated with the epithelial or mesenchymal state. Although the Table lists attributes of the polar states, presence of intermediate states is the rule.

E-cadherin is a multifunctional, highly phosphorylated outer cell membrane protein active in securing epithelial-to-epithelial cell adherence. E-cadherin undergoes a shift in molecular weight going from 125 to $115 \mathrm{kDa}$ during iron overload, reversing back to 125 $\mathrm{kDa}$ after $\mathrm{Fe}++$ chelation [25]. The intracellular domain of E-cadherin binds beta-catenin. Thus, less surface E-cadherin, often mirrored by increase of $\mathrm{N}$-cadherin $[26,27]$, results in less adherence to neighbor cells facilitating tumor cell spreading. It is also coupled to loss of intracellular beta-catenin sequestration, making increased beta-catenin available for transport into nucleus where it is a malignancy-associated transcription factor. An interesting question is whether E-cadherin changes reflect or contribute to mediating (or both) EMT [28]. Vimentin is one of several markers in tissues undergoing EMT, as listed in Table 1. Immunohistochemical and mRNA study of GB biopsy tissues showed that high vimentin expression was associated with significantly shorter survival compared with GB with lower vimentin expression [29].

Among the multiple regulators of, and triggers to, EMT in GB is also epigenetic regulation by small noncoding RNAs or microRNAs (miRNA, a sequence of 20 to 25 nucleotides). miRNA have already been described to play a major role in GB growth, proliferation, migration and invasion processes [30]. More recently and more specifically, microRNAs have also been shown to play various roles in GB's EMT process generally, and specifically by increasing transforming growth factor-beta (TGF-beta) [31, 32], a fact of particular importance in our use of TGF-beta inhibitor pirfenidone (vide infra, Section 3.a. on pirfenidone).

It would be wrong to view EMT as a single core element of malignancy. Both EMT and MET are crucial attributes for vigorous malignant growth. Without either process cancer would be easier to cure with modern techniques, both processes must be addressed for effective treatment. EMT is crucial for release of malignant cells to blood or lymph, but MET is crucial for metastasis establishment and growth [3], corresponding to the oncology aphorism "go or grow". Otherwise said, while EMT enhances cells leaving the primary tumor mass, MET is the process that enhances distant colony establishment and growth $[3,33]$. GB patients have readily identifiable circulating GIC. These have markers and characteristics of post-EMT cells [34] indicating EMT as an active process in GB. Cancer cell epithelial or mesenchymal state seems not to be strictly binary states. Intermediate states are the rule rather than the exception. To summarize, EMT-MET phenotypic shuttling is a central and defining feature of GB, with GIC residing in two phenotypic gradients each of which culminates in one specific pole : higher proliferative activity with angiogenesis (epithelial state) or higher migratory activity with attenuated mitosis (mesenchymal state) [35].

Multiple triggers to EMT initiation are present as part of the natural biology of GB: hypoxia, inflammation, acidic milieu, epidermal growth factor (EGF) signaling are examples [35]. Current treatments with cytotoxic chemotherapy (temozolomide in the case of GB), surgical tissue disruption and radiation have all been recognized as triggers for remaining viable cells to enter EMT, details given in Section 2. below.

GB heterogeneity of driver mutations [36, 37] extends likewise to heterogeneity of EMT drivers. In examining pancreatic adenocarcinoma intratumoral heterogeneity Dembinski and Krauss found large but incomplete overlap between slowly cycling cell subpopulation and those expressing commonly accepted stem cell markers (e.g. ALDH, CD44, CD133) and behaviors [38]. Most enlightening was their finding that EMT characteristics were stimulated largely by $\mathrm{Hh}$ and TGF-beta signaling, and crucially such stimulation and marker changes were accompanied by decreased epidermal growth factor receptor (EGFR) expression. This implies a dynamic shuttling or see-saw process where TGF-beta and Hh signaling increase EMT but decrease EGFR dependency, partially explaining erlotinib failures.

The hypoxic microenvironmental islands characteristic of GB are drivers of EMT. Tumor hypoxia, via the Hypoxia Inducible Factors (HIF-1 $\alpha$ and HIF-2 $\alpha$ ), directly or indirectly control the expression of several EMT transcriptional regulators such as Snail, Slug, Twist1 or ZEB1/2 [39]. Aberrant reduced expression of E-cadherin, the HIF or the EMT regulators is correlated with more aggressive tumors and poor prognosis [12, 13]. Hypoxia also results in the recruitment of myeloid cells (e.g. macrophages and neutrophils), which can secrete TGF-beta, and other signaling proteins resulting in subsequent EMT promotion [40]. Of note, these secreted factors are known HIF inducers in GB [41] thus adding another level of complexity to EMT initiation in GB.

Additionally, hypoxia-induced EMT particularly occurs in areas of CXCL12 stimulation of outer cell membrane CXCR4 [42] with increasing N-cadherin and matrix metalloproteinase-9 (MMP9) [43]. This may be relevant to the GB remission case reported by Rios et al [44]. These authors reported an unusual durable response in a GB patient treated with adjuvant therapy consisting of temozolomide and a weekly dose of plerixafor, a CXCR4 inhibitor, together with lapatinib, high dose metformin and niacinamide [44]. What role the individual components played is unknown, but high dose metformin use may be noteworthy (Section 3.f.). 
Tabouret et al have shown in paired primary and recurrent resection tissues that post-radiation recurrent GB had upregulated CXCR4/CXCL12 signaling [45]. However, a clinical trial of plerixafor in GB failed to show benefit [ClinicalTrials.gov Identifier:NCT01339039]. Data by Pharm et al may hint at the reasons why this trial failed despite the durable response described by Rios et al using plerixafor and a number of clinical and preclinical reports confirming the importance of CXCR4/CXCL12 in GB growth and invasion [46]. Pharm et al found that CXCR4/CXCL12 signaling in GB exists in a mutually inverse relationship (see-saw, reciprocal) with signaling of vascular endothelial growth factor receptor (VEGFR) [46].

Since several reports show metformin-mediated reduction of VEGFR function in both preclinical [47-49] and in mice fed a high fat diet and clinically in polycystic ovarian syndrome (PCOS) and type 2 diabetes settings [50-52], inhibiting both systems- VEGFR function by metformin and CXCR4/CXCL12 by plerixafor, might be required to achieve a durable antitumor response.

To summarize, preventing EMT during GB treatment might be a constructive step. Below are a sextet of already-marketed drugs with evidence that they inhibit in coordinated fashion one or another aspect of the EMT process. They are designed to be given all together to GB patients, during and alongside the standard therapeutic temozolomide based protocol for glioblastoma [53]. In Section 2. below we present data indicating that all 3 glioblastoma treatment modalities- primary resection, radiation as well as temozolomide provoke EMT entry in glioblastoma, EIS Regimen might well be started even before biopsy and continued through end of temozolomide.

\section{TREATMENT TRIGGERS EMT}

It should not be considered odd that our mainstay current treatment modalities for cancer- cytotoxic chemotherapy, radiation, and resection- have all been shown to enhance or trigger EMT and thus have tumor growth-promoting aspects. In chess, fencing, or other forms of combat, including other fields of medicine, actions that in sum further our goals and prolong life, also contain within those actions elements that work against our goal. The chess aphorism "All moves create weaknesses and strengths" applies to all areas of medical intervention. So our job is to assess that balance in deciding to offer a treatment. The EIS Regimen is designed to run alongside all phases of initial GB standard treatments - surgical resection, temozolomide, and radiation - with the purpose to diminish the EMT triggered by treatment.

\section{Surgery induces EMT}

That surgery induces EMT in tissues within the operative field should not be surprising in that EMT is an integral feature of normal wound healing and is triggered by any tissue integrity disruption [54].

We give here a few examples of tissue disruption by surgery or even simple needle core biopsy triggering EMT. Breast cancer fine needle biopsy engages EMT in mice [55]. Of potential clinical concern, incision biopsy of oral squamous cell carcinoma causes tumor-associated macrophages to produce increased local TGF-beta [56, 57] that in turn contributes to local immunosuppression and EMT as outlined in Section 3.a. below. Similarly, during human breast cancer diagnosis, the site of needle biopsies show recruitment of inflammatory cells that cause an increased proliferation rate of surrounding breast cancer cells [58]. Standard transrectal ultrasound guided prostate biopsy results in detectable prostate cancer cells in the circulation in half of patients [59]. Incisional biopsy of oral squamous cell carcinoma results in $16 \%$ of patients having post-biopsy circulating tumor cells indicative of post-EMT status [60] whereas excision wide enough to not disrupt the tumor tissue integrity did not result in postoperative circulating tumor cells [61 ].

Conclusion: GB tissue disruption might engage EMT in scattered residual cells.

\section{Cytotoxic chemotherapy induces EMT}

Temozolomide enhances migration and EMT in some- but not all- ex vivo glioma cell lines and fresh patient glioblastoma cells [62]. Temozolomide exposure induces several EMT markers including high vimentin, TGF-beta, beta-catenin, and fibronectin in T98G glioma cells [6]. In testing breast cancer cells for doxorubicin cytotoxicity, 2 independent groups found that those cells not killed by doxorubicin were induced to undergo EMT and those post-EMT cells were relatively doxorubicin resistant $[63,64]$. Similar doxorubicin induction of EMT was confirmed in triple negative breast cancer [64] and in hepatocellular carcinoma cells $[65,66]$, colon cancer cells [67] and non-small cell lung cancer cells [68]. Gastric cancer cells exposed to sublethal doxorubicin were phenotypically mesenchymal and overexpressed vimentin, twist and beta-catenin [69]. 5-FU induced EMT and increased TGF-beta in colon cancer cells [70]. Most relevant to our subject, doxorubicin also induces EMT in glioma cells [71]. KM12L4 and HT29 colon cancer cell lines exposed to oxaliplatin lose E-cadherin, increase vimentin, and become motile while becoming more resistant to oxaliplatin [72]. During chronic exposure to paclitaxel, ovarian cancer cell lines take on a mesenchymal phenotype, lose E-cadherin and increase expression of vimentin and fibronectin [73].

Conclusion: Current cytotoxic chemotherapy drugs tend to engage EMT programs. 


\section{Radiation induces EMT}

We have many examples where radiation that didn't kill exposed cells, triggered them to undergo EMT. Radioresistant glioma cells exhibit a specific signature enriched in genes belonging to the EMT process [74]. Reviews in 2014 and again this year (2017) of collected data from multiple different cancers make a strong argument that a) ionizing radiation induces increased metastasis potential and enhanced invasiveness of surviving cancer cells and $b$ ) it does so via induction of EMT programs $[75,76]$.

Empirically, radiation enhancement of migration and triggering of EMT specifically in GB can be readily demonstrated [77-83].

Radiation enhanced centrifugal migration of U87 glioma cells implanted in mice and also increased brain levels of IL-1, PGE2, IL-6, and TNF-alpha (see Section 3.d below) [77]. U251 glioma cells were triggered to enter EMT and migrate after exposure to X-rays [79]. Non-gamma ionizing radiation at intermediate doses also triggered glioma cells to migrate and express EMT markers. At doses above intermediate, cell death occurred, below intermediate dose failed to induce EMT [80]. That "cells surviving radiation can become more aggressive and invasive" was confirmed in 2 independent studies GB [81, 82]. Most instructive was the study of Desmarais et al with radiation of rats with orthotopic implanted glioma cells. Radiation enhanced the implanted glioma cells' migration and shortened survival compared to control rats implanted with the same glioma cells but not radiated [83].

Similar ionizing radiation induction of migration and other EMT attributes can be demonstrated in other cancers. For example non-lethal X-radiation at $0.4 \mathrm{~Gy} / \mathrm{min}$ induced migration, individual cell morphology changes typical of EMT, strong upregulation of EMT mediating transcription factors Snail and Twist, decreased E-cadherin and increased vimentin and fibronectin in MCF-7 breast cancer cells [84]. Nearly identical increases in motility and phenotype changes with concomitant decreases in E-cadherin and increases in vimentin and fibronectin have been described in irradiated colorectal cancer cell lines [85]. Human non-small cell lung cancer cells surviving 10 Gy radiation showed increased motility and increased MMP-2/-9 [86]. Dramatic demonstration of the development of microtentacles after colon cancer cell exposure to 5Gy X-ray can be seen in scanning electron micrographs [87]. Endometrial cancer cells [88] and squamous esophageal cancer cells [89] take on typical EMT phenotypic changes and increase migration after gamma radiation. Biopsy from the radiated field in rectal cancer shows regions of cells having undergone EMT with elevated Slug, Snail, and vimentin [90].

Two breast, 2 colon and 2 lung adenocarcinoma cell lines subjected to 2 Gy increased vimentin and motility while taking on typical mesenchymal morphology [91].
Altogether, these data strongly suggest that GB cell response to radiation contribute to the EMT process and the acquisition of an invasive and aggressive phenotype.

Conclusion: So while radiation of the post-resection area improves overall survival, it also induces EMT in the few surviving cells that have migrated deep into brain, setting the stage for later aggressive regrowth of tumor. Or as Niccolo Machiavelli (1469 - 1527) said in 1513 "People should either be caressed or crushed. If you do them minor damage they will get their revenge; but if you cripple them there is nothing they can do. If you need to injure someone, do it in such a way that you do not have to fear their vengeance." EIS Regimen was crafted with that in mind.

\section{THE EIS REGIMEN: EMT TRIGGERS, MAINTENANCE FACTORS, AND 6 CURRENTLY AVAILABLE DRUGS TO INHIBIT BOTH}

The EMT-triggering targets presented here have been selected based in part on a) their having readily available repurposed drugs to inhibit them that $b$ ) are already FDA, EMA, ANSM (French FDA equivalent) and Health Canada approved for use in humans. The guiding precept was that we must treat today's disease in today's patient with the medicines and tools we have available today. Additionally, the growing cost of medical care worldwide, particularly in oncology is a further incentive to repurpose already marketed, clinically used nononcology drugs to augment effectiveness of traditional oncology drugs. The EIS Regimen uses medicines that have been well-proven to be safe and effective in their original indication. If they will be likewise effective as adjunct in treating GB must be tested.

\section{Inhibiting TGF-beta: pirfenidone}

Of all the EIS Regimen drugs, the one with the strongest evidence for benefit during GB treatment is pirfenidone. Pirfenidone is a $185 \mathrm{Da}$ drug first approved to treat idiopathic pulmonary fibrosis [92, 93]. It has since been investigated in treating hepatic fibrosis and other diseases where excessive fibrosis is a problem. It is welltolerated, side effects do not usually necessitate stopping. Side effects of pirfenidone tend to be gastrointestinal and generally mild - nausea, dyspepsia, vomiting, anorexia, or less commonly rash - but all without long term sequelae $[94,95]$.

Pirfenidone works in part by blocking TGF-beta signaling $[92,94,96]$. TGF-beta is a $25 \mathrm{kDa}$ signaling protein proteolytically clipped from a large precursor protein. TGF-beta signaling is a major driver of EMT in cancer generally $[97,98]$ and in GB's EMT specifically $[12,13,99-102]$. 
TGF-beta is a facilitating element of many cancers by promoting angiogenesis, immune suppression and EMT induction [103]. After cell surface binding to its heteromeric receptor complex serine/threonine kinase, multiple processes including activation of nuclear transcription factors and cytoplasmic cytoskeleton changes - are set in motion and initiate and sustain EMT [104]. Multiple intermediary transcription factors activated by TGF-beta including Snail, Slug, Twist, SIP1/ $\mathrm{ZEB}$, and E47, down regulate E-cadherin expression and engage EMT related programs [105]. Chronic TGFbeta-mediated stimulation in both cancer or pathologic wound healing may drive excess extracellular matrix and collagen synthesis and deposition [106]. TGF-beta induces phosphorylation of Smad, p38, Akt, and smooth muscle actin and collagen mRNA levels - all elements of EMTin normal pulmonary fibroblasts during development of pulmonary fibrosis. All these changes can be inhibited by pirfenidone [107]. Pirfenidone inhibits experimentally TGF-beta driven migration and EMT in normal epithelia [108, 109].

Experimental unilateral ureteral obstruction in rats results in tubulointerstitial changes characteristic of EMT- increased TGF-beta1, type III collagen, $\alpha$-SMA, S100A4, fibronectin and reduced expression of E-cadherin. Pirfenidone treatment tended to diminish these changes [110], reducing obstruction provoked EMT and renal fibrosis. Pirfenidone also inhibited TGFbeta driven collagen and fibronectin overproduction in nonsmall cell lung cancer cell lines [111]. In dextran-induced murine colitis, pirfenidone reduced the elevated TGFbeta mRNA, SMAD signaling, and consequent fibrosis [112]. Pirfenidone inhibited migration of ex vivo TGFbeta stimulated nasal polyp fibroblasts concomitantly with blocking TGF-beta-induced SMAD phosphorylation [104].

These data are effects we expect pirfenidone to likewise do during GB treatment. Of added benefit during $\mathrm{GB}$, pirfenidone has activity also in inhibiting TNF-alpha and platelet derived growth factor (PDGF) [96], both growth factors implicated in driving GB growth. TGF-beta triggers prostate cancer cell motility and enhances bone marrow cell recruitment to the growing tumor stroma. $[113,114]$.

An early (1994) study showed that while TGFbeta enhanced invasiveness and migration of glioma cells, it also decreased mitotic rate, indicative of EMT induction [115]. A recent study (2016) showed that an experimental peptide TGF-beta inhibitor, P144, decreased GB invasion, migration, and increased apoptosis [116]. microRNA-564 mediated decrease in TGF-beta inhibited proliferation and invasiveness of U87 glioma cells [Jiang]. Phytoderived delphinidin inhibited TGFbeta-mediated increases in fibronectin and migration of U87 glioma cells by interfering with translation factor SMAD and others, downstream from TGF-beta receptors
[117]. None of the latter 3 anti-TGF-beta agents- P114 peptide, microRNA-564, or delphinidin- are marketed pharmaceuticals available to treat GB patients today. Pirfenidone is.

Ohshio et al have shown that blocking TGF-beta release from lung cancer cells reduced their motility and invasiveness, increased their expression of E-cadherin and reverted their morphology to epithelial from mesenchymal but had no effect on the cells viability [118]. Similarly, in hepatocellular carcinoma TGF-beta synthesized and released by tumor infiltrating monocytes, drives the proper carcinoma cells' EMT [119]. A parallel relationship between monocyte lineage cells and malignant phenotype has been described in GB as well [120].

Circulating IL-6 and TGF-beta levels are elevated in chronic hepatitis C. After 2 years treatment with pirfenidone (400 mg, 3 times daily), levels of both cytokines were lowered by $\sim 50 \%$ [121]. See Section 3.d. below for discussion on advantages of diminishing IL-6. Retinal pigment epithelial cells after exposure to TGF-beta undergo phenotypic, biochemical marker and enhanced migration changes typical of EMT. Exposure to pirfenidone prevented these effects of TGF-beta by preventing SMAD translocation to nucleus [122]. Pirfenidone inhibits TGF-beta increases after bleomycin exposure in rats as well [123]. TGF-beta signaling in connection with another EIS drug, metformin, is discussed under section 3.f.

Pirfenidone was first suggested as a potentially useful treatment adjunct for GB in 2007 [124]. In this Section we detailed further evidence that TGF-beta is an important GB growth factor and major trigger for GB cells' EMT. Inhibition of TGF-beta expression in malignant glioma cells by pirfenidone is worth investigating as adjunctive treatment alongside of current primary GB treatment with resection, temozolomide and radiation.

\section{Inhibiting RANKL: quetiapine}

Quetiapine is a $383 \mathrm{Da}$ generic psychiatric drug originally marketed to treat psychoses. It has since been found to have other attributes, including norepinephrine reuptake inhibition and strong antihistamine effects leading to adjunctive use in treating depression and insomnia, respectively.

Our addition of quetiapine to the EIS Regimen hinges on a single report showing that quetiapine inhibits the Receptor Activator of Nuclear Factor Kappa B Ligand (RANKL) signaling [125]. Secondary consideration recommending quetiapine's addition was that it is well tolerated in a non-psychiatric population- it will not add to side effect burden.

RANKL becomes overexpressed in parallel with vimentin and $\mathrm{N}$-cadherin during TGF-beta-induced EMT in prostate cancer cell lines [126]. RANKL signaling may 
be more of a mediator of EMT behaviors than a trigger to initiate or maintain EMT programs. An interesting dataset connects RANKL to EMT. RANKL-activation of RANK increased expression of vimentin, N-cadherin, Snail, and Twist, decreased the expression of E-cadherin and drove EMT in normal breast acinar cells and a number of cancers including breast cancer [127], hepatocellular carcinoma [128, 129], endometrial [130, 131], lung [132] and prostate cancer [126].

GB secreted RANKL enhances GB invasive motility in part by paracrine signaling to surrounding nonmalignant astrocytes, triggering these astrocytes to secrete TGF-beta that in turn facilitates centrifugal glioma cell migration/invasion [133]. Thus the EIS Regimen attempts to undermine the RANKL and TGF-beta mediated growth enhancing cycle between glioma cell and surrounding normal astrocytes by coordinated inhibition with quetiapine and pirfenidone.

\section{Inhibiting beta-catenin-mediated canonical Wnt signaling: rifampin}

Rifampin (synonymous with rifampicin) is an 823 Da antibiotic introduced to clinical use in the 1960's, used today largely for treating tuberculosis, Hansen's disease, treatment resistant Staphylococcal, and H.pylori infections [134]. Rifampin functions in EIS Regimen to a) reduce microglial activation and b) inhibit Wnt/beta-catenin signaling (these 2 attributes might be related).

a) Rifampin is neuroprotective by inhibiting microglial activation and is in active study in Parkinson's disease on that basis $[135,136]$.

b) Wnt signaling forms an important growth element in many cancers $[137,138]$ including in GB $[139,140]$. Wnt signaling is divided into canonical and non-canonical [141]. Canonical Wnt signals through the $92 \mathrm{kDa}$ intracellular transcription factor beta-catenin. After Wnt ligand binding, beta-catenin is translocated to the nucleus where it binds to cognate DNA recognition sequences and promotes transcription of a number of target genes. In the absence of Wnt ligand, beta-catenin is degraded via the ubiquitin-proteasome pathway [142]. Poly-phosphorylation and poly-ubiquitination mark beta-catenin molecules doomed for proteasomal destruction [142]. beta-catenin can also be sequestered in cytoplasm by binding to the intracellular domain of E- or $\mathrm{N}$-cadherin and therefore become unavailable to serve as a transcription factor in nucleus [137-140].

Experimental beta-catenin agonists enhance glioma cell migration that is impaired in the presence of betacatenin inhibitors [143]. For instance, tetrandrine is a 623 Da phytoderived molecule that inhibits glioma cell (and urothelial cancer cell) migration by blocking beta-catenin translocation to the nucleus [144, 145]. EIS Regimen uses rifampin to do the same.
In early 2016, an unusual case of retarded progression in a non-small cell lung cancer patient being treated for tuberculosis with rifabutin led Li et al [146] to experimentally investigate the anti-cancer effect of rifabutin. Rifabutin is an $847 \mathrm{Da}$ antibiotic closely related to the older rifampin. It was found that rifabutin prevented Wnt-mediated beta-catenin's protection from proteasomal degradation and by this mechanism inhibited non-small cell cancer's growth both in vitro and in an in vivo xenograft model [146]. Since rifabutin doesn't cross the $\mathrm{BBB}$ but the closely related rifampin does, the latter would be preferable in inhibiting canonical Wnt/ beta-catenin nuclear signaling in GB. Canonical Wnt is a convergence point for many signaling systems triggering EMT, promoting glioma growth, and driving centrifugal glioma cell motility [147-156].

beta-catenin signaling upregulation forms part of glioma cells' development of temozolomide resistance [151]. Upregulation of beta-catenin signaling as a response to ionizing radiation is a component mediating GB's EMT response after radiation exposure [154] (as discussed in Section 2.c. above). Experimental, non-marketed beta-catenin signaling inhibitors inhibited experimental glioma's growth $[145,149,152,156]$.

Inhibiting the canonical Wnt/beta-catenin signaling with rifampin is a worthwhile strategy to explore in GB treatment.

\section{Inhibiting Rac1-mediated non-canonical Wnt signaling and IL-6: naproxen}

Non-canonical Wnt signaling occurs without participation of beta-catenin [140, 141]. Rac1 (acronym for ras-related C3 botulinum toxin substrate 1) is a 21 $\mathrm{kDa}$ GTPase that serves as a transducer, an intracellular link between non-canonical Wnt signaling events and end-effects in the nucleus [139-141]. Experimental Rac1 inhibition potentiates cytostasis and cytotoxicity by imatinib, gefitinib [157] and erlotinib in GB [158]. Experimental Rac1 inhibition inhibits colon cancer cells' migration as well [159].

Naproxen is a 230 Da, commonly used cyclooxygenase (COX) inhibitor, marketed as an analgesic. Cerebrospinal fluid (CSF) naproxen levels not higher than 3 microM may be achieved under usual treatment conditions. Oprea et al have reported $\mathrm{EC}_{50}$ for Rac1 of R-naproxen being 18 microM [160]. Given the achievable brain tissue levels of naproxen as compared to Rac1 inhibition data by Oprea and coworkers, naproxen would not be the ideal Rac1 inhibitor. Albeit something more potent would be preferable and medicinal chemistry studies aimed to development of more effective Rac1 inhibitors are warranted, preclinical investigations on the potential therapeutic effect of naproxen on GIC-driven orthotopic GB may provide useful indications on the role 
of Rac1 in GB's EMT. Again, although not ideal we must fight GB with the tools we have at hand.

IL-6 is a cofactor promoting GB's EMT. Collected data on growth promotion and apoptosis inhibition functions of IL-6 in GB up to 2011 was reviewed by Yeung and coworkers [161 ] Since then circulating IL-6 was found elevated in GB [162] as was CSF IL-6 level [163].

COX inhibitors tend to reduce IL- 6 by decreasing intracellular cAMP [164-166]. Specific recent examples of this: naproxen clinically reduced IL-6 in IL-6overproducing pheochromocytoma [167], in sera of patient with osteoarthritis [168], in subchondral osteoartrthritis osteoblasts [169], and in osteoarthritis patient synovial cells ex vivo [170]. Also in rheumatoid arthritis plasma and synovial fluid show increased IL-6 that is decreased by naproxen treatment [171]], and in a cardiac myxoma patient with elevated IL-6 [172]. In accord with what we know of intracellular control of IL-6 generation, COX inhibition generally reduces circulating IL-6. IL-6 suppression may be a worthy target during GB treatment.

It is established that GB cells synthesize IL-6 and it functions as a significant growth and migration enhancing factor [173-194].

Selected examples: Exogenous IL-6 enhanced glioma cell migration in vitro [173]. A pharmaceutical monoclonal anti-IL-6 antibody inhibited glioma cell proliferation [174], radiation induced increased IL-6 synthesis (cf Section 2.c. above) [176] contributing to glioblastoma related reduced immune function. There is an IL- 6 based positive feedback loop in glioblastoma where extracellular IL-6 results in intracellular STAT3 phosphorylation (activation) that in turn upregulates glioblastoma cells' IL-6 synthesis [181]. Glioblastoma show IL-6 gene amplification and patients with greater degree of amplification have shorter overall survival $[184,185]$. Peripheral blood mononuclear cells from GB patients secrete abnormally large amounts of IL-6 as well [190]. Immunohistochemical IL-6 staining of GB tends to be heavier in perinecrotic areas [190].

In a parallel fashion reminiscent of radiation induction of EMT (see Section 2.c. above), IL-6 synthesis by GB cells was stimulated by intermediate dose radiation whereas low or high dose radiation did not increase IL-6 [180]. Earlier studies have shown that GB cells increase IL-6 synthesis and release after sublethal radiation and that this release increases with time over the first post-radiation day [191]. Aspirin, a balanced COX1-2 inhibitor reduced GB cell synthesis of IL-6 and induced cell death, an effect that was counteracted by adding exogenous IL-6 [192].

However, 2 clinical failures to find naproxen lowering of IL-6 (after spinal surgery and in rheumatoid arthritis) $[195,196]$ are of concern. This matter mandates monitoring IL-6 during EIS Regimen to determine if naproxen is in fact working as intended.

The observation that IL-6 can transactivate EGFR in GB in the absence of any EGFR ligand in GB [197], may help to explain why the EGFR inhibitor erlotinib was not effective clinically in treating GB tumors even when these are growth suppressed by erlotinib in vitro and overexpress EGFR in vivo [198].

In conclusion, limiting IL-6 function seems to be an eminently worthwhile goal in treating glioblastoma. Naproxen might not be an ideal drug to use for that, but naproxen is cheap, readily available, well-tolerated, and the drug we have today.

\section{Inhibiting hedgehog: itraconazole}

Itraconazole, an old $706 \mathrm{Da}$ antifungal drug, is undergoing a renaissance of interest for its anticancer effects $[199,200]$. The primary mode of anti-cancer action is inhibition of Hh signaling [199, 200]. Hh is an important driver of GB growth [201-207]. Hh signals through intracellular transcription factor Gli $[205,206]$. Gli1-driven transcription induces EMT via induction of Snail, a repressor of E-cadherin in many other cancers.

Itraconazole inhibits release of Gli1 thus keeping it sequestered in the cytoplasm [205]. GB patients with low Gli1 expression had longer overall survival [202]. The experimental Hh signaling inhibitor cyclopamine, or suppressing Gli1 expression by using siRNA interference led to decreased cell proliferation and enhanced apoptosis in U87 glioma cell line [208].

In preclinical studies itraconazole inhibition of Hh signaling inhibited growth of breast cancer [209], melanoma [210], and endometrial cancer [211].

\section{Activating AMPK: metformin}

Metformin is a $129 \mathrm{Da}$ drug in common first line use when type 2 diabetes is diagnosed [212 ]. In 2013, metformin was called "a rising star to fight (EMT) in oncology" by Barriere and coworkers who recounted multiple putative modes of metformin's anti-cancer action [213]. Further, Del Barco et al have reviewed the empirical epidemiological evidence for a metformin anticancer effect [214] and Chae et al the relevant clinical studies [215].

Across many cancers a large chart review shows decreased mortality in patient's treated with metformin [216 ] although the effect has not been large. Increased lactate secretion, reduced oxygen consumption, inhibition of mitochondrial inner membrane I complex activity (inner membrane NADH ubiquinone oxidoreductase), and activation of AMPK-signaling have been proposed as mechanisms for metformin's anticancer effects [217]. To what degree one or the other of these mechanisms is the consequence of one of the other listed mechanisms is unknown. Inhibition of the mitochondrial respiratory chain complex 1 is the leading candidate for a primary 
mode of anti-cancer action [218]. By inhibiting function of mitochondrial respiratory chain complex 1 , mitochondrial ATP production and oxygen consumption are decreased. Compensatory increases in lactate and shift to relative reliance on glycolytic ATP production result in AMPK activation, with mTOR function consequent to that. Decreased proliferation, cell cycle arrest, autophagy, apoptosis and other forms of cell death would then follow from this ensemble.

AMPK is a ubiquitous heterotrimeric protein acting as a kinase with multiple identified targets [219]. Metformin, through inhibition of the mitochondrial respiratory chain complex 1, activates AMPK [220, 221] that in turn suppresses several transcription factors including Snail and Slug [28, 222]. Circulating leukocytes of metformin-treated diabetes patients had hypomethylated E-cadherin promoters and increased E-cadherin levels [28]. Metformin specifically inhibits TGFbeta -induced EMT in non-small cell lung cancer cell lines [223]. Independent studies showed that metformin inhibited TGF-beta-stimulated loss of E-cadherin and gain of vimentin $[106,224]$ as well the decrease of N-cadherin and prostate cancer cell motility [224].

Decreasing $\mathrm{N}$-cadherin expression can also be an AMPK-independent mode of metformin action in reversing or inhibiting EMT [225]. TGF-beta activated intracellular transcription factors Snail and Twist and cervical cancer EMT are also diminished after metformin [106, 226]. Human endometrial cancer biopsy tissue from patients on metformin had more E-cadherin compared to patients on other anti-diabetes agents [227]. This bodes well for our use of metformin to inhibit EMT during primary GB treatment.

Although tumor bed radiation after GB resection is standard treatment of GB and has proven survival benefit, radiation does participate in enhancing residual GB cell migration as outlined in Section 2.C. above. Metformin inhibits radiation induced EMT features and increased motility in esophageal squamous cell carcinoma cells where metformin also reduced radiationinduced expression of mesenchymal markers vimentin and N-cadherin and reduced transcription factors Slug, Snail, and Twist [228]. In a parallel manner, exposure to docetaxel decreases prostate cancer cells' mitosis rate, but increases motility, lowers E-cadherin expression, increases MMP-9 and changes morphology typical of EMT. Metformin partially reversed this docetaxel-induced increased motility, lowered E-cadherin, and increased MMP-9 [229].

Metformin also reduced EMT phenotypic changes observed in lung adenocarcinoma cells exposed to TGF-beta, by decreasing Snail2, Twist, and vimentin expression, while increasing E-cadherin [230]. Similarly, metformin also increased E-cadherin, decreased $\mathrm{N}$-cadherin and MMP-9 in a xenografted mouse gastric cancer model [231]. In melanoma cells metformin partially reversed EMT and in vitro colony formation triggered by low $\mathrm{pH}$ [232]. Metformin increased E-cadherin and phosphorylated AMPK, while decreasing N-cadherin in hepatocellular carcinoma cells [233].

Triple negative breast cancer (TNBC, cells not expressing estrogen receptor, progesterone receptor, or HER2) are particularly aggressive. In these patients, elevated TGF-beta production further worsens the patient's prognosis. In vitro, metformin attenuated the TGF-betastimulated TNBC cell growth, invasion and motility [234]. Metformin inhibited EMT in cell lines of thyroid [235], non-small cell lung [236] and prostate cancer [237], and reversed EMT in non-small cell lung [238], breast [239] and prostate cancer [240]. In melanoma, metformin increased E-cadherin and inhibited cell motility, migration and invasion [241].

Experimental renal ischemia-reperfusion results in tubulointerstitial fibrosis accompanied by increased TGFbeta, IL-6, and vimentin with decreased E-cadherin. All these, changes may be partially reversed by metformin [242]. In proximal tubular epithelial cells TGF-beta1 treatment causes a decrease in AMPK phosphorylation and activation together with increased fibronectin and alpha-smooth muscle actin expression and decrease in E-cadherin. Metformin inhibited these TGF-beta induced changes by increasing phosphorylated AMPK [243].

Metformin reversed 17beta-estradiol-induced EMT in endometrial adenocarcinoma cells via an AMPK activating step [222]. Activation of AMPK by metformin inhibited TGF-beta-induced Smad2/3phosphorylation, increase in IL-6 and fibronectin in cancer cells [244], indicative of EMT inhibition. AMPK activation reduces DNA promoter activity resulting downstream to TGFbeta 1 and a slight decrease in serum TGF-beta in diabetic patients [245].

In non-small cell lung cancer cells, the inverse relationship between rising IL-6 expression and falling E-cadherin expression was inhibited by metformin [236]. TGF-beta induced EMT in prostate cancer cells, increasing E-cadherin, vimentin and Slug, effects mitigated by metformin [246]. Thus metformin is a promising partner drug for pirfenidone.

As positive data accrues, using metformin as an adjunct to cancer therapies becomes a more and more attractive strategy. For instance, in hepatocellular carcinoma cells metformin alone gave considerable growth inhibition and augmented cytotoxicity of cytotoxic drugs 5-FU, doxorubicin, cisplatin increases oxidative stress synergistically leading to increased apoptosis in treated cells [247].

Metformin was synergistic with sorafinib in increasing intracellular ROS, decreasing efflux pump activity and increasing apoptosis in glioma cells [248]. That metformin augmented temozolomide GIC killing in GB explant culture was shown in 2011 [249] and again independently in 2016 [250]. Metformin's cytotoxic 
activity to glioma cells is somewhat selective for the GIC subpopulation [251]. Metformin inhibits glioma cell proliferation at lower concentrations and proliferation plus migration at higher concentrations [252]. Metformin exposure enhanced cytotoxic effects to glioma cells of either temozolomide or radiation and retarded glioma xenograft growth [253]. By progressive temozolomide exposure over 9 months, glioma cells resistant to temozolomide were developed. Exposure to metformin several days before exposure to temozolomide more than reverted these cells' sensitivity to temozolomide. The authors confirmed metformin retardation of glioma growth in a xenograft model [254].

Leidgens et al found glioma cell exposure to metformin resulted in decreased glioma cell proliferation and increased AMPK activation, as found by others, but also inhibition phosphorylation of STAT3 in [255].

Despite being rather hydrophilic, metformin achieves approximately equal plasma and brain tissue levels. In rats after single dose oral metformin administration, $28 \mathrm{micromol} / \mathrm{l}$ plasma and $14 \mathrm{micromol} / \mathrm{kg}$ brain tissue were measured [256]. The range of metformin plasma levels typically seen in asymptomatic diabetes patients is unusually wide for a therapeutic drug, reflecting its safety [257]. Of considerable additional potential benefit, metformin reduced glioma-induced brain edema in a rat model [258].

\section{SAFETY}

\section{Pirfenidone}

In clinical practice pirfenidone often has no side effects. Mild nausea in 23\%, rash /photosensitivity in 20\% (treated minus placebo) of patients were most common side effects when treating idiopathic pulmonary fibrosis [259]. These side effects were generally well tolerated.

\section{Quetiapine}

Quetiapine has a circulating half-life of 7 hours but its dopaminergic (at D2) and serotonergic (at 5-HT2A) receptor antagonistic occupancy is transient. It has significant antidepressant and antipsychotic properties for both of which it is in wide use world wide [260]. Quetiapine is quite well tolerated also in non-psychiatric populations. Some daytime sedation is common after starting quetiapine but this usually wears off after several day's use. It should only be given once daily at bedtime. This day sedation commonly recurs after each dose increase but again wears off after several day's use. Importantly for a drug with anti-psychotic properties, quetiapine-related extrapyramidal signs and symptoms do not differ from placebo [260].

\section{Rifampin}

Rifampin has a $4 \mathrm{hr}$ half-life and is relatively safe at doses under $1.2 \mathrm{~g} /$ day, under which adverse or side effect risk is small, although in rare cases serious [261]. Druginduced hepatitis is recognized as a rare possibility. Since rifampin is a strong inducer of P450 3A4 [262] and use with a strong $3 \mathrm{~A} 4$ inhibitor, itraconazole, is envisioned, the net effect will be unclear so caution would be required when using other drugs that may be influenced by this catabolizing system. Rifampin also strongly increases level and activity of CYP2A6, CYP2C8, 2C9, and 2B6 [262].

\section{Naproxen}

Naproxen is so well tolerated that it is widely available around the world over-the-counter (i.e. available without a prescription), the most common side effect being gastrointestinal irritation and microbleeds. Stomach or duodenal ulceration occurs rarely. Prior H.pylori eradication and administration with a proton pump inhibitor will reduce that risk even further. Naproxen is a balanced COX1/COX2 inhibitor, has a $14 \mathrm{hr}$ half-life, is metabolized by multiple hepatic P450 enzymes, prominent among which are 1A2, 2C8 and 2C9 and has been marketed since the 1970's. Naproxen hasn't the cardiovascular risks of other COX inhibitors and in fact does share with aspirin some of that drug's cardioprotective antiplatelet function [263].

\section{Itraconazole}

Itraconazole is a lipophilic, $24 \mathrm{hr}$ half-life, broad spectrum anti-fungal drug [264]. Serum levels $<17.1$ $\mathrm{mg} / \mathrm{L}$ are associated with fewer side effects than are higher levels. Out of 9065 patients treated with itraconazole, 17\% had mild GI upset, liver function elevation in $5 \%$, rash in $3 \%, 2 \%$ hypokalemia, $1 \%$ headache, but only 1 case of hepatitis, with multiple rare cases of various other side effects [264]. If a proton pump inhibitor is concomitantly used, itraconazole must be given with orange or lemon juice to achieve good absorption.

\section{Metformin}

Most people starting metformin experience no side effect. Metformin is one of the safer anti-diabetic drugs as it does not induce hypoglycemia. Mild and transient GI upset occurs in 5\% of non-insulin-dependent diabetes patients starting metformin. Rare lactic acidosis has been reported [265, 266]. Most of ingested metformin appears unchanged in urine and feces $[265,266]$. 


\section{CONCLUSIONS}

All three arms of current GB treatment - surgery, cytotoxic chemotherapy with temozolomide, and radiation - all tend to engage EMT programs. Post-EMT GB cells are more aggressive, more treatment resistant, and are in a high migration, apoptosis resistant state. The EIS Regimen was developed with the aim of limiting this inherent negative consequence of current GB treatment. The EIS Regimen uses only already-marketed drugs, repurposed for their ancillary attributes in inhibiting one or another of the EMT triggers, as described above in Section 3.

As a preliminary step the efficacy of the EIS regimen towards GB might best be investigated in preclinical survival studies on immunodeficient mice bearing GIC-driven orthotopic tumors. This is presently the most reliable and informative animal model we have albeit an imperfect one- for exploring the efficacy of novel treatments against GB, prior to clinical Phase I/II studies.

In the meantime, given the lethality of GB, the ubiquity of recurrence after primary treatment, the paucity of treatments we have to offer after recurrence, it could be reasonable to add the EIS Regimen to initial current standard in a small pilot study to test the hypothesis of this paper, that the EIS Regimen with inhibit treatmentinduced EMT and thereby delay recurrence. Blocking EMT with the EIS Regimen was designed to be best applied peri-operatively, even before first biopsy, and used continuously during radiation and primary treatment with temozolomide for at least one year.

This paper proposes the simple idea that, by combining individual interventions that might be weak individually, we may get an additive therapeutic effect, particularly when the drug effects are coordinated as we have attempted to do. The expected safety profile of the ensemble of EIS Regimen drugs is based on the wellknown safety profile of the individual drugs.

We are fully aware that some other drivers of EMT that have been identified are not addressed by EIS Regimen. Functional redundancy may be a major problem when trying to pharmacologically block malignancypromoting pathways and processes like EMT, given its expected safety and the usual outcome of GB as it stands today, the EIS Regimen is a rational option that we might explore with profit today using today's tools.

\section{Highlights}

- $\quad$ EMT is an element of malignant process where tumor cells become loose, more motile but less mitotic and less sensitive to cytotoxic drugs and radiation

- EMT is a central initial process in establishment of metastases or tumor spreading in the organ of primary occurrence such as brain.
- Standard cancer treatment modalities- cytotoxic chemotherapy, radiation and surgical resection, all tend to provoke or increase EMT.

- Six older drugs- itraconazole, metformin, naproxen, pirfenidone, quetiapine, and rifampin have good preclinical evidence that they can be repurposed to interfere with EMT process and therefore be of adjunctive benefit when treating cancer generally, glioblastoma specifically, to run alongside of standard current treatment.

\section{Abbreviations}

AMPK, AMP kinase; CSF, cerebrospinal fluid; COX, cyclooxygenase; EGFR, epidermal growth factor receptor; EMT, epithelial to mesenchymal transition; EIS, epithelial to mesenchymal transition inhibiting sextet; GB, glioblastoma; GIC, glioma initiating cells; Hh, Hedgehog signaling; HIF, Hypoxia Inducible Factors; MMP, matrix metalloproteinase; MET, mesenchymal to epithelial transition; miRNA, microRNA; PDGF, platelet derived growth factor; RANKL, receptor activator of NFkB ligand; TGF-beta, transforming growth factor-beta; TNBC, triple negative breast cancer; VEGFR, vascular endothelial growth factor receptor.

\section{ACKNOWLEDGMENTS}

G.F. was partially supported by Compagnia San Paolo, Turin, Italy, grant 2015.0643 - ID ROL: 9834.

\section{CONFLICTS OF INTEREST}

There is no conflict of interest.

\section{REFERENCES}

1. Chaffer CL, San Juan BP, Lim E, Weinberg RA. EMT, cell plasticity and metastasis. Cancer Metastasis Rev. 2016 Nov 22. [Epub ahead of print].

2. Tang H, Massi D, Hemmings BA, Mandala M, Hu Z, Wicki A, Xue G. AKT-ions with a TWIST between EMT and MET. Oncotarget. 2016;7:62767-62777. doi: 10.18632/ oncotarget.11232.

3. Tan EJ, Olsson AK, Moustakas A. Reprogramming during epithelial to mesenchymal transition under the control of TGFbeta. Cell Adh Migr. 2015;9:233-46. doi:10.4161/193 36918.2014.983794.

4. Sato R, Semba T, Saya H, Arima Y. Concise Review: Stem Cells and Epithelial Mesenchymal Transition in Cancer: Biological Implications and Therapeutic Targets. Stem Cells. 2016;34:1997-2007. doi:10.1002/stem.2406.

5. Yeung KT, Yang J. Epithelial-mesenchymal transition in tumor metastasis. Mol Oncol. 2017;11:28-39. doi: 


\subsection{2/1878-0261.12017.}

6. Kubelt C, Hattermann K, Sebens S, Mehdorn HM, HeldFeindt J. Epithelial to mesenchymal transition in paired human primary and recurrent glioblastomas. Int J Oncol. 2015;46:2515-25. doi: 10.3892/ijo.2015.2944.

7. Adamski V, Schmitt AD, Flüh C, Synowitz M, Hattermann $\mathrm{K}$, Held-Feindt J. Isolation and characterization of fast migrating human glioma cells in the progression of malignant gliomas. Oncol Res. 2017;25:341-353. doi: 10. 3727/096504016X14737243054982.

8. Romaguera-Ros M, Peris-Celda M, Oliver-De La Cruz J, Carrion-Navarro J, Perez-Garcia A, Garcia-Verdugo JM, Ayuso-Sacido A. Cancer-initiating enriched cell lines from human glioblastoma: Preparing for drug discovery assays. Stem Cell Rev. 2012;8:288-298.

9. Vecchio D, Daga A, Carra E, Marubbi D, Baio G, Neumaier CE, Vagge S, Corvo R, Pia Brisigotti M, Louis Ravetti J, Zunino A, Poggi A, Mascelli S, et al. Predictability, efficacy and safety of radiosensitization of glioblastoma-initiating cells by the ATM inhibitor KU-60019. Int J Cancer. 2014;135:479-491.

10. Sarkar S, Zemp FJ, Senger D, Robbins SM, Yong VW. ADAM-9 is a novel mediator of tenascin-C-stimulated invasiveness of brain tumor-initiating cells. Neuro Oncol. 2015;17:1095-105. doi: 10.1093/neuonc/nou362.

11. Jayachandran A, Dhungel B, Steel JC. Epithelial-tomesenchymal plasticity of cancer stem cells: therapeutic targets in hepatocellular carcinoma. J Hematol Oncol. 2016;9:74. doi:10.1186/s13045-016-0307-9.

12. Iwadate $Y$. Epithelial-mesenchymal transition in glioblastoma progression. Oncol Lett. 2016;11:1615-1620.

13. Iwadate Y, Matsutani T, Hirono S, Shinozaki N, Saeki N. Transforming growth factor-beta and stem cell markers are highly expressed around necrotic areas in glioblastoma. J Neurooncol. 2016;129:101-7. doi:10.1007/s11060-0162145-6.

14. Annabi B, Lachambre MP, Plouffe K, Sartelet H, Béliveau R. Modulation of invasive properties of CD133+ glioblastoma stem cells: a role for MT1-MMP in bioactive lysophospholipid signaling. Mol Carcinog. 2009;48:910-9. doi:10.1002/mc.20541.

15. Cheng L, Wu Q, Guryanova OA, Huang Z, Huang Q, Rich $\mathrm{JN}$, Bao S. Elevated invasive potential of glioblastoma stem cells. Biochem Biophys Res Commun. 2011;406:643-8. doi: 10.1016/j.bbrc.2011.02.123.

16. Polyak K, Weinberg RA. Transitions between epithelial and mesenchymal states: acquisition of malignant and stem cell traits. Nat Rev Cancer. 2009;9:265-73. doi: 10.1038/ nrc2620.

17. Iser IC, Pereira MB, Lenz G, Wink MR. The Epithelialto-Mesenchymal Transition-Like Process in Glioblastoma: An Updated Systematic Review and In Silico Investigation. Med Res Rev. 2017;37:271-313. doi: 10.1002/med.21408.

18. Whipple RA, Matrone MA, Cho EH, Balzer EM, Vitolo
MI, Yoon JR, Ioffe OB, Tuttle KC, Yang J, Martin SS. Epithelial-to-mesenchymal transition promotes tubulin detyrosination and microtentacles that enhance endothelial engagement. Cancer Res. 2010;70:8127-37. doi: 10.1158/0008-5472.CAN-09-4613.

19. Kim YW, Koul D, Kim SH, Lucio-Eterovic AK, Freire PR, Yao J, Wang J, Almeida JS, Aldape K, Yung WK. Identification of prognostic gene signatures of glioblastoma: a study based on TCGA data analysis. Neuro Oncol. 2013;15:829-39. doi: 10.1093/neuonc/not024.

20. Du B, Shim JS. Targeting Epithelial-Mesenchymal Transition (EMT) to Overcome Drug Resistance in Cancer. Molecules. 2016;21. doi:10.3390/molecules21070965.

21. Pala A, Karpel-Massler G, Kast RE, Wirtz CR, Halatsch ME. Epidermal to Mesenchymal Transition and Failure of EGFR-Targeted Therapy in Glioblastoma. Cancers (Basel). 2012;4:523-30. doi: 10.3390/cancers4020523.

22. Kolbl AC, Jeschke U, Andergassen U. The Significance of Epithelial-to-Mesenchymal Transition for Circulating Tumor Cells. Int J Mol Sci. 2016;17. doi: 10.3390/ ijms 17081308 .

23. Liu H, Zhang X, Li J, Sun B, Qian H, Yin Z. The biological and clinical importance of epithelial-mesenchymal transition in circulating tumor cells. J Cancer Res Clin Oncol. 2015;141:189-201. doi: 10.1007/s00432-0141752-x.

24. Wang H, Stoecklein NH, Lin PP, Gires O. Circulating and disseminated tumor cells: diagnostic tools and therapeutic targets in motion. Oncotarget. 2017;8:1884-1912. doi: 10.18632/oncotarget.12242.

25. Fujikura Y, Krijt J, Povysil C, Melkova Z, Prikryl P, Vokurka M, Necas E. Iron Overload Causes Alterations of E-Cadherin in the Liver. Folia Biol (Praha). 2016;62:95102.

26. Reszec J, Szkudlarek M, Hermanowicz A, Bernaczyk PS, Mariak Z, Chyczewski L. N-cadherin, beta-catenin and connexin 43 expression in astrocytic tumours of various grades. Histol Histopathol. 2015;30:361-71. doi:10.14670/ HH-30.361.

27. Utsuki S, Sato Y, Oka H, Tsuchiya B, Suzuki S, Fujii K. Relationship between the expression of E-, N-cadherins and beta-catenin and tumor grade in astrocytomas. J Neurooncol. 2002;57:187-92.

28. Banerjee P, Surendran H, Chowdhury DR, Prabhakar K, Pal R. Metformin mediated reversal of epithelial to mesenchymal transition is triggered by epigenetic changes in E-cadherin promoter. J Mol Med (Berl). 2016;94:13971409.

29. Lin L, Wang G, Ming J, Meng X, Han B, Sun B, Cai J, Jiang C. Analysis of expression and prognostic significance of vimentin and the response to temozolomide in glioma patients. Tumour Biol. 2016;37:15333-15339.

30. Costa PM, Cardoso AL, Mano M, de Lima MC. MicroRNAs in glioblastoma: role in pathogenesis and 
opportunities for targeted therapies. CNS Neurol Disord Drug Targets. 2015;14:222-38.

31. Li Q, Cheng Q, Chen Z, Peng R, Chen R, Ma Z, Wan X, Liu J, Meng M, Peng Z, Jiang B. MicroRNA-663 inhibits the proliferation, migration and invasion of glioblastoma cells via targeting TGF- $\beta 1$. Oncol Rep. 2016;35:1125-34. doi: 10.3892/or.2015.4432.

32. He X, Liu Z, Peng Y, Yu C. MicroRNA-181c inhibits glioblastoma cell invasion, migration and mesenchymal transition by targeting TGF- $\beta$ pathway. Biochem Biophys Res Commun. 2016;469:1041-8. doi: 10.1016/j. bbrc.2015.12.021.

33. Gradilone A, Raimondi C, Nicolazzo C, Petracca A, Gandini O, Vincenzi B, Naso G, Agliano AM, Cortesi E, Gazzaniga P. Circulating tumour cells lacking cytokeratin in breast cancer: the importance of being mesenchymal. J Cell Mol Med. 2011;15:1066-70. doi: 10.1111/j.15824934.2011.01285.x.

34. Sullivan JP, Nahed BV, Madden MW, Oliveira SM, Springer S, Bhere D, Chi AS, Wakimoto H, Rothenberg SM, Sequist LV, Kapur R, Shah K, Iafrate AJ, et al. Brain tumor cells in circulation are enriched for mesenchymal gene expression. Cancer Discov. 2014;4:1299-309. doi: 10.1158/2159-8290.CD-14-0471.

35. Ichikawa T, Otani Y, Kurozumi K, Date I. Phenotypic Transition as a Survival Strategy of Glioma. Neurol Med Chir (Tokyo). 2016;56:387-95. doi:10.2176/nmc.ra.20160077.

36. Soeda A, Hara A, Kunisada T, Yoshimura S, Iwama T, Park DM. The evidence of glioblastoma heterogeneity. Sci Rep. 2015;5:7979. doi: 10.1038/srep07979.

37. Reinartz R, Wang S, Kebir S, Silver DJ, Wieland A, Zheng T, Küpper M, Rauschenbach L, Fimmers R, Shepherd TM, Trageser D, Till A, Schäfer N, et al. Functional Subclone Profiling for Prediction of Treatment-Induced Intratumor Population Shifts and Discovery of Rational Drug Combinations in Human Glioblastoma. Clin Cancer Res. 2017;23:562-574. doi: 10.1158/1078-0432.CCR-15-2089.

38. Dembinski JL, Krauss S. Characterization and functional analysis of a slow cycling stem cell-like subpopulation in pancreas adenocarcinoma. Clin Exp Metastasis. 2009;26:611-23. doi: 10.1007/s10585-009-9260-0.

39. Yang L, Lin C, Wang L, Guo H, Wang X. Hypoxia and hypoxia-inducible factors in glioblastoma multiforme progression and therapeutic implications. Exp Cell Res. 2012;318:2417-26. doi: 10.1016/j.yexcr.2012.07.017.

40. Cooper LA, Gutman DA, Chisolm C, Appin C, Kong J, Rong Y, Kurc T, Van Meir EG, Saltz JH, Moreno CS, Brat DJ. The tumor microenvironment strongly impacts master transcriptional regulators and gene expression class of glioblastoma. Am J Pathol. 2012;180:2108-19. doi: 10.1016/j.ajpath.2012.01.040.

41. Piao Y, Liang J, Holmes L, Zurita AJ, Henry V, Heymach JV, de Groot JF. Glioblastoma resistance to anti-VEGF therapy is associated with myeloid cell infiltration, stem cell accumulation, and a mesenchymal phenotype. Neuro Oncol. 2012;14:1379-92. doi: 10.1093/neuonc/nos158.

42. Joseph JV, Conroy S, Pavlov K, Sontakke P, Tomar T, Eggens-Meijer E, Balasubramaniyan V, Wagemakers M, den Dunnen WF, Kruyt FA. Hypoxia enhances migration and invasion in glioblastoma by promoting a mesenchymal shift mediated by the HIF1 $\alpha$-ZEB1 axis. Cancer Lett. 2015;359:107-16. doi:10.1016/j.canlet.2015.01.010.

43. Yao C, Li P, Song H, Song F, Qu Y, Ma X, Shi R, Wu J. CXCL12/CXCR4 Axis Upregulates Twist to Induce EMT in Human Glioblastoma. Mol Neurobiol. 2016;53:3948-53. doi: 10.1007/s12035-015-9340-x.

44. Rios A, Hsu SH, Blanco A, Buryanek J, Day AL, McGuire MF, Brown RE. Durable response of glioblastoma to adjuvant therapy consisting of temozolomide and a weekly dose of AMD3100 (plerixafor), a CXCR4 inhibitor, together with lapatinib, metformin and niacinamide. Oncoscience. 2016;3:156-63. doi:10.18632/oncoscience.311.

45. Tabouret E, Tchoghandjian A, Denicolai E, Delfino C, Metellus P, Graillon T, Boucard C, Nanni I, Padovani L, Ouafik L, Figarella-Branger D, Chinot O. Recurrence of glioblastoma after radio-chemotherapy is associated with an angiogenic switch to the CXCL12-CXCR4 pathway. Oncotarget. 2015;6:11664-75. doi: 10.18632/ oncotarget.3256.

46. Pham K, Luo D, Siemann DW, Law BK, Reynolds BA, Hothi P, Foltz G, Harrison JK. VEGFR inhibitors upregulate CXCR4 in VEGF receptor-expressing glioblastoma in a TGF $\beta R$ signaling-dependent manner. Cancer Lett. 2015;360:60-7. doi:10.1016/j.canlet.2015.02.005.

47. Zhu M, Zhang Q, Wang X, Kang L, Yang Y, Liu Y, Yang L, Li J, Yang L, Liu J, Li Y, Zu L, Shen Y, Qi Z. Metformin potentiates anti-tumor effect of resveratrol on pancreatic cancer by down-regulation of VEGF-B signaling pathway. Oncotarget. 2016;7:84190-84200. doi: 10.18632/ oncotarget.12391.

48. Wang J, Li G, Wang Y, Tang S, Sun X, Feng X, Li Y, Bao G, Li P, Mao X, Wang M, Liu P. Suppression of tumor angiogenesis by metformin treatment via a mechanism linked to targeting of HER2/HIF-1 $\alpha / \mathrm{VEGF}$ secretion axis. Oncotarget. 2015;6:44579-92. doi: 10.18632/ oncotarget.6373.

49. Tadakawa M, Takeda T, Li B, Tsuiji K, Yaegashi N. The anti-diabetic drug metformin inhibits vascular endothelial growth factor expression via the mammalian target of rapamycin complex 1/hypoxia-inducible factor-1 $\alpha$ signaling pathway in ELT-3 cells. Mol Cell Endocrinol. 2015;399:18. doi:10.1016/j.mce.2014.08.012.

50. Dallaglio K, Bruno A, Cantelmo AR, Esposito AI, Ruggiero L, Orecchioni S, Ciaraldi TP, Aroda V, Mudaliar SR, Henry RR. Inflammatory cytokines and chemokines, skeletal muscle and polycystic ovary syndrome: effects of pioglitazone and metformin treatment. Metabolism. 2013;62:1587-96. doi:10.1016/j.metabol.2013.07.004. 
51. Ersoy C, Kiyici S, Budak F, Oral B, Guclu M, Duran C, Selimoglu H, Erturk E, Tuncel E, Imamoglu S. The effect of metformin treatment on VEGF and PAI-1 levels in obese type 2 diabetic patients. Diabetes Res Clin Pract. 2008;81:56-60. doi: 10.1016/j.diabres.2008.02.006.

52. Cheng F, Zhao L, Wu Y, Huang T, Yang G, Zhang Z, Wu Y, Jia F, Wu J, Chen C, Liu D. Serum vascular endothelial growth factor B is elevated in women with polycystic ovary syndrome and can be decreased with metformin treatment. Clin Endocrinol (Oxf). 2016;84:386-93. doi: 10.1111/ cen. 12950 .

53. Stupp R, Tonn JC, Brada M, Pentheroudakis G, ESMO Guidelines Working Group. High-grade malignant glioma: ESMO clinical practice guidelines for diagnosis, treatment and follow-up. Ann Oncol. 2010; 21:v190-3.

54. Stone RC, Pastar I, Ojeh N, Chen V, Liu S, Garzon KI, Tomic-Canic M. Epithelial mesenchymal transition in tissue repair and fibrosis. Cell Tissue Res. 2016;365:495-506. doi: 10.1007/s00441-016-2464-0.

55. Mathenge EG, Dean CA, Clements D, Vaghar-Kashani A, Photopoulos S, Coyle KM, Giacomantonio M, Malueth B, Nunokawa A, Jordan J, Lewis JD, Gujar SA, Marcato $\mathrm{P}$, et al. Core needle biopsy of breast cancer tumors increases distant metastases in a mouse model. Neoplasia. 2014;16:950-60. doi:10.1016/j.neo.2014.09.004.

56. Oishi S, Takano R, Tamura S, Tani S, Iwaizumi M, Hamaya Y, Takagaki K, Nagata T, Seto S, Horii T, Osawa S, Furuta T, Miyajima H, Sugimoto K. M2 polarization of murine peritoneal macrophages induces regulatory cytokine production and suppresses T-cell proliferation. Immunology. 2016;149:320-328. doi:10.1111/imm.12647.

57. Schmidt A, Zhang XM, Joshi RN, Iqbal S, Wahlund C, Gabrielsson S, Harris RA, Tegnér J. Human macrophages induce $\mathrm{CD} 4(+) \mathrm{Foxp} 3(+)$ regulatory $\mathrm{T}$ cells via binding and re-release of TGF-beta. Immunol Cell Biol. 2016;94:74762. doi: 10.1038/icb.2016.34.

58. Szalayova G, Ogrodnik A, Spencer B, Wade J, Bunn J, Ambaye A, James T, Rincon M. Human breast cancer biopsies induce eosinophil recruitment and enhance adjacent cancer cell proliferation. Breast Cancer Res Treat. 2016;157:461-74. doi: 10.1007/s10549-016-3839-3.

59. Hara N, Kasahara T, Kawasaki T, Bilim V, Tomita Y, Obara K, Takahashi K. Frequency of PSA-mRNA-bearing cells in the peripheral blood of patients after prostate biopsy. Br J Cancer. 2001;85:557-62.

60. Dyavanagoudar S, Kale A, Bhat K, Hallikerimath S. Reverse transcriptase polymerase chain reaction study to evaluate dissemination of cancer cells into circulation after incision biopsy in oral squamous cell carcinoma. Indian $\mathrm{J}$ Dent Res. 2008;19:315-9.

61. Kusukawa J, Suefuji Y, Ryu F, Noguchi R, Iwamoto O, Kameyama T. Dissemination of cancer cells into circulation occurs by incisional biopsy of oral squamous cell carcinoma. J Oral Pathol Med. 2000;29:303-7.
62. Adamski V, Schmitt AD, Flüh C, Synowitz M, Hattermann $\mathrm{K}$, Held-Feindt J. Isolation and characterization of fast migrating human glioma cells in the progression of malignant gliomas. Oncol Res. 2017;25:341-353. doi: 10. 3727/096504016X14737243054982.

63. Li W, Liu C, Tang Y, Li H, Zhou F, Lv S. Overexpression of Snail accelerates adriamycin induction of multidrug resistance in breast cancer cells. Asian Pac J Cancer Prev. 2011;12:2575-80.

64. Li QQ, Xu JD, Wang WJ, Cao XX, Chen Q, Tang F, Chen ZQ, Liu XP, Xu ZD. Twist1 mediated adriamycin-induced epithelial-mesenchymal transition relates to multidrug resistance and invasive potential in breast cancer cells. Clin Cancer Res. 2009;15:2657-65. doi: 10.1158/1078-0432. CCR-08-2372.

65. Pan JX, Wang F, Ye LY. Doxorubicin-induced epithelial-mesenchymal transition through SEMA 4A in hepatocellular carcinoma. Biochem Biophys Res Commun. 2016;479:610-614. doi: 10.1016/j.bbrc.2016.09.167.

66. Xu T, Zhang J, Chen W, Pan S, Zhi X, Wen L, Zhou Y, Chen BW, Qiu J, Zhang Y, Yang Q, Feng X, Bai X, et al. ARK5 promotes doxorubicin resistance in hepatocellular carcinoma via epithelial-mesenchymal transition. Cancer Lett. 2016;377:140-8. doi:10.1016/j.canlet.2016.04.026.

67. Wang X, Jiang R, Cui E, Feng W, Guo H, Gu D, Tang C, Xue T, Bao Y. COUP-TFII suppresses colorectal carcinoma resistance to doxorubicin involving inhibition of epithelial mesenchymal transition. Am J Transl Res. 2016;8:39213929.

68. Li R, Wu S, Chen X, Xu H, Teng P, Li W. miR-223/FBW7 axis regulates doxorubicin sensitivity through epithelial mesenchymal transition in non-small cell lung cancer. Am J Transl Res. 2016;8:2512-24.

69. Han RF, Ji X, Dong XG, Xiao RJ, Liu YP, Xiong J, Zhang QP. An epigenetic mechanism underlying doxorubicin induced EMT in the human BGC-823 gastric cancer cell. Asian Pac J Cancer Prev. 2014;15:4271-4.

70. Romano G, Santi L, Bianco MR, Giuffrè MR, Pettinato M, Bugarin C, Garanzini C, Savarese L, Leoni S, Cerrito MG, Leone BE, Gaipa G, Grassilli E, et al. The TGF- $\beta$ pathway is activated by 5 -fluorouracil treatment in drug resistant colorectal carcinoma cells. Oncotarget. 2016;7:22077-91. doi:10.18632/oncotarget.7895.

71. Liu Q, Sun Y, Zheng JM, Yan XL, Chen HM, Chen JK, Huang HQ. Formononetin sensitizes glioma cells to doxorubicin through preventing EMT via inhibition of histone deacetylase 5. Int J Clin Exp Pathol. 2015;8:643441.

72. Yang AD, Fan F, Camp ER, van Buren G, Liu W, Somcio R, Gray MJ, Cheng H, Hoff PM, Ellis LM. Chronic oxaliplatin resistance induces epithelial-to-mesenchymal transition in colorectal cancer cell lines. Clin Cancer Res. 2006;12:4147-53.

73. Kajiyama H, Shibata K, Terauchi M, Yamashita M, Ino K, 
Nawa A, Kikkawa F. Chemoresistance to paclitaxel induces epithelial-mesenchymal transition and enhances metastatic potential for epithelial ovarian carcinoma cells. Int J Oncol. 2007;31:277-83.

74. Meng J, Li P, Zhang Q, Yang Z, Fu S. A radiosensitivity gene signature in predicting glioma prognostic via EMT pathway. Oncotarget. 2014; 5:4683-93. doi: 10.18632/ oncotarget.2088.

75. Moncharmont C, Levy A, Guy JB, Falk AT, Guilbert M, Trone JC, Alphonse G, Gilormini M, Ardail D, Toillon RA, Rodriguez-Lafrasse C, Magné N. Radiationenhanced cell migration/invasion process: a review. Crit Rev Oncol Hematol. 2014;92:133-42. doi: 10.1016/j. critrevonc.2014.05.006.

76. Lee SY, Jeong EK, Ju MK, Jeon HM, Kim MY, Kim $\mathrm{CH}$, Park HG, Han SI, Kang HS. Induction of metastasis, cancer stem cell phenotype, and oncogenic metabolism in cancer cells by ionizing radiation. Mol Cancer. 2017;16:10. doi:10.1186/s12943-016-0577-4.

77. Edalat L, Stegen B, Klumpp L, Haehl E, Schilbach K, Lukowski R, Kühnle M, Bernhardt G, Buschauer A, Zips D, Ruth P, Huber SM. BK K+ channel blockade inhibits radiation induced migration/brain infiltration of glioblastoma cells. Oncotarget. 2016;7:14259-78. doi:10.18632/oncotarget.7423.

78. Falk AT, Moncharmont C, Guilbert M, Guy JB, Alphonse G, Trone JC, Rivoirard R, Gilormini M, Toillon RA, Rodriguez-Lafrasse C, Magné N. Radiation-induces increased tumor cell aggressiveness of tumors of the glioblastomas. Bull Cancer. 2014;101:876-80. doi:10.1684/ bdc.2014.1946.

79. Xiong Y, Ji W, Fei Y, Zhao Y, Wang L, Wang W, Han M, Tan C, Fei X, Huang Q, Liang Z. Cathepsin L is involved in X-ray-induced invasion and migration of human glioma U251 cells. Cell Signal. 2017;29:181-191. doi: 10.1016/j. cellsig.2016.10.012.

80. Zaboronok A, Isobe T, Yamamoto T, Sato E, Takada K, Sakae T, Tsurushima H, Matsumura A. Proton beam irradiation stimulates migration and invasion of human U87 malignant glioma cells. J Radiat Res. 2014;55:283-7. doi:10.1093/jrr/rrt119.

81. Kegelman TP, Wu B, Das SK, Talukdar S, Beckta JM, Hu B, Emdad L, Valerie K, Sarkar D, Furnari FB, Cavenee WK, Wei J, Purves A, et al. Inhibition of radiation-induced glioblastoma invasion by genetic and pharmacological targeting of MDA-9/Syntenin. Proc Natl Acad Sci USA. 2017;114:370-375. doi: 10.1073/pnas.1616100114.

82. Mahabir R, Tanino M, Elmansuri A, Wang L, Kimura T, Itoh T, Ohba Y, Nishihara H, Shirato H, Tsuda M, Tanaka S. Sustained elevation of Snail promotes glial mesenchymal transition after irradiation in malignant glioma. Neuro Oncol. 2014;16:671-85. doi: 10.1093/neuonc/not239.

83. Desmarais G, Charest G, Therriault H, Shi M, Fortin D, Bujold R, Mathieu D, Paquette B. Infiltration of F98 glioma cells in Fischer rat brain is temporary stimulated by radiation. Int J Radiat Biol. 2016;92:444-50. doi:10.1080/0 9553002.2016.1175682.

84. Zhang X, Li X, Zhang N, Yang Q, Moran MS. Low doses ionizing radiation enhances the invasiveness of breast cancer cells by inducing epithelial-mesenchymal transition. Biochem Biophys Res Commun. 2011; 412:188-92. doi:10.1016/j.bbrc.2011.07.074.

85. Kawamoto A, Yokoe T, Tanaka K, Saigusa S, Toiyama Y, Yasuda H, Inoue Y, Miki C, Kusunoki M. Radiation induces epithelial-mesenchymal transition in colorectal cancer cells. Oncol Rep. 2012;27:51-7. doi: 10.3892/ or.2011.1485.

86. Tsutsumi K, Tsuda M, Yazawa N, Nakamura H, Ishihara S, Haga H, Yasuda M, Yamazaki R, Shirato H, Kawaguchi H, Nishioka T, Ohba Y. Increased motility and invasiveness in tumor cells that survive 10 Gy irradiation. Cell Struct Funct. 2009;34:89-96.

87. Blockhuys S, Liu N, Agarwal NR, Enejder A, Loitto V, Sun XF. X-radiation enhances the collagen type I strap formation and migration potentials of colon cancer cells. Oncotarget. 2016;7:71390-71399. doi:10.18632/ oncotarget.12111.

88. Tsukamoto H, Shibata K, Kajiyama H, Terauchi M, Nawa A, Kikkawa F. Irradiation induced epithelial-mesenchymal transition (EMT) related to invasive potential in endometrial carcinoma cells. Gynecol Oncol. 2007;107:500-4.

89. Su Z, Li G, Liu C, Ren S, Tian Y, Liu Y, Qiu Y. Ionizing radiation promotes advanced malignant traits in nasopharyngeal carcinoma via activation of epithelialmesenchymal transition and the cancer stem cell phenotype. Oncol Rep. 2016;36:72-8. doi: 10.3892/or.2016.4768.

90. Tato-Costa J, Casimiro S, Pacheco T, Pires R, Fernandes A, Alho I, Pereira P, Costa P, Castelo HB, Ferreira J, Costa L. Therapy-Induced Cellular Senescence Induces Epithelialto-Mesenchymal Transition and Increases Invasiveness in Rectal Cancer. Clin Colorectal Cancer. 2016;15:170-178. e3. doi:10.1016/j.clcc.2015.09.003.

91. Zhou YC, Liu JY, Li J, Zhang J, Xu YQ, Zhang HW, Qiu LB, Ding GR, Su XM, Mei-Shi, Guo GZ. Ionizing radiation promotes migration and invasion of cancer cells through transforming growth factor-beta-mediated epithelialmesenchymal transition. Int J Radiat Oncol Biol Phys. 2011;81:1530-7. doi:10.1016/j.ijrobp.2011.06.1956.

92. Ogura T, Azuma A, Inoue Y, Taniguchi H, Chida K, Bando M, Niimi Y, Kakutani S, Suga M, Sugiyama Y, Kudoh S, Nukiwa T. All-case post-marketing surveillance of 1371 patients treated with pirfenidone for idiopathic pulmonary fibrosis. Respir Investig. 2015;53:232-41. doi: 10.1016/j. resinv.2015.06.001.

93. Maher TM. Pirfenidone in idiopathic pulmonary fibrosis. Drugs Today (Barc). 2010;46:473-82. doi: 10.1358/ dot.2010.46.7.1488336.

94. Anderson A, Shifren A, Nathan SD. A safety evaluation of pirfenidone for the treatment of idiopathic pulmonary 
fibrosis. Expert Opin Drug Saf. 2016;15:975-82. doi:10.1 080/14740338.2016.1187129.

95. Hughes G, Toellner H, Morris H, Leonard C, Chaudhuri N. Real World Experiences: Pirfenidone and Nintedanib are Effective and Well Tolerated Treatments for Idiopathic Pulmonary Fibrosis. J Clin Med. 2016;5. doi: 10.3390/ jcm5090078.

96. Lopez-de la Mora DA, Sanchez-Roque C, MontoyaBuelna M, Sanchez-Enriquez S, Lucano-Landeros S, Macias-Barragan J, Armendariz-Borunda J. Role and New Insights of Pirfenidone in Fibrotic Diseases. Int J Med Sci. 2015;12:840-7. doi:10.7150/ijms.11579.

97. Cantelli G, Crosas-Molist E, Georgouli M, Sanz-Moreno V. TGFbeta-induced transcription in cancer. Semin Cancer Biol. 2017;42:60-69. doi: 10.1016/j.semcancer.2016.08.009.

98. Lin RL, Zhao LJ. Mechanistic basis and clinical relevance of the role o transforming growth factor- $\beta$ in cancer. Cancer Biol Med. 2015;12:385-93. doi:10.7497/j.issn.2095-3941.2015.0015.

99. Nickl-Jockschat T, Arslan F, Doerfelt A, Bogdahn U, Bosserhoff A, Hau P. An imbalance between Smad and MAPK pathways is responsible for TGF-beta tumor promoting effects in high-grade gliomas. Int $\mathrm{J}$ Oncol. 2007;30:499-507.

100. Singh SK, Fiorelli R, Kupp R, Rajan S, Szeto E, Lo Cascio C, Maire CL, Sun Y, Alberta JA, Eschbacher JM, Ligon KL, Berens ME, Sanai N, et al. Post-translational Modifications of OLIG2 Regulate Glioma Invasion through the TGF-beta Pathway. Cell Rep. 2016;16:950-66. doi:10.1016/j.celrep.2016.06.045.

101. Caja L, Bellomo C, Moustakas A. Transforming growth factor $\beta$ and bone morphogenetic protein actions in brain tumors. FEBS Lett. 2015;589:1588-97. doi:10.1016/j. febslet.2015.04.058.

102. Kaminska B, Kocyk M, Kijewska M. TGF beta signaling and its role in glioma pathogenesis. Adv Exp Med Biol. 2013;986:171-87. doi:10.1007/978-94-007-4719-7_9.

103. Khan Z, Marshall JF. The role of integrins in TGF $\beta$ activation in the tumour stroma. Cell Tissue Res. 2016;365:657-73. doi: 10.1007/s00441-016-2474-y.

104. Shin JM, Park JH, Park IH, Lee HM. Pirfenidone inhibits transforming growth factor beta1-induced extracellular matrix production in nasal polyp-derived fibroblasts. Am J Rhinol Allergy. 2015;29:408-13. doi:10.2500/ ajra.2015.29.4221.

105. Lindsey S, Langhans SA. Crosstalk of Oncogenic Signaling Pathways during Epithelial Mesenchymal Transition. Front Oncol. 2014;4:358. doi:10.3389/fonc.2014.00358.

106. Cufi S, Vazquez-Martin A, Oliveras-Ferraros C, MartinCastillo B, Joven J, Menendez JA. Metformin against TGFbeta-induced epithelial-to-mesenchymal transition (EMT): from cancer stem cells to aging-associated fibrosis. Cell Cycle. 2010;9:4461-8.

107. Conte E, Gili E, Fagone E, Fruciano M, Iemmolo M,
Vancheri C. Effect of pirfenidone on proliferation, TGFbeta-induced myofibroblast differentiation and fibrogenic activity of primary human lung fibroblasts. Eur J Pharm Sci. 2014;58:13-9. doi: 10.1016/j.ejps.2014.02.014.

108. Wang J, Yang Y, Xu J, Lin X, Wu K, Yu M. Pirfenidone inhibits migration, differentiation, and proliferation of human retinal pigment epithelial cells in vitro. Mol Vis. 2013;19:2626-35.

109. Yang Y, Ye Y, Lin X, Wu K, Yu M. Inhibition of pirfenidone on TGF-beta induced proliferation, migration and epithelial-mesenchymal transition of human lens epithelial cells line SRA01/04. PLoS One. 2013;8:e56837. doi:10.1371/journal.pone.0056837.

110. Li Z, Liu X, Wang B, Nie Y, Wen J, Wang Q, Gu C. Pirfenidone suppresses MAPK signaling pathway to reverse epithelial-mesenchymal transition and renal fibrosis. Nephrology (Carlton). 2016; 22:589-597. doi: 10.1111/ nep. 12831 .

111. Hisatomi K, Mukae H, Sakamoto N, Ishimatsu Y, Kakugawa T, Hara S, Fujita H, Nakamichi S, Oku H, Urata Y, Kubota H, Nagata K, Kohno S. Pirfenidone inhibits TGF-betal induced over-expression of collagen type I and heat shock protein 47 in A549 cells. BMC Pulm Med. 2012;12:24. doi: 10.1186/1471-2466-12-24.

112. Li G, Ren J, Hu Q, Deng Y, Chen G, Guo K, Li R, Li Y, Wu L, Wang G, Gu G, Li J. Oral pirfenidone protects against fibrosis by inhibiting fibroblast proliferation and TGF-beta signaling in a murine colitis model. Biochem Pharmacol. 2016;117:57-67. doi: 10.1016/j.bcp.2016.08.002.

113. Barcellos-de-Souza P, Comito G, Pons-Segura C, Taddei ML, Gori V, Becherucci V, Bambi F, Margheri F, Laurenzana A, Del Rosso M, Chiarugi P. Mesenchymal Stem Cells are Recruited and Activated into Carcinoma-Associated Fibroblasts by Prostate Cancer Microenvironment-Derived TGF-beta. Stem Cells. 2016;34:2536-2547. doi: 10.1002/stem.2412.

114. Guo X, Xue H, Shao Q, Wang J, Guo X, Chen X, Zhang J, Xu S, Li T, Zhang P, Gao X, Qiu W, Liu Q, et al. Hypoxia promotes glioma-associated macrophage infiltration via periostin and subsequent M2 polarization by upregulating TGF-beta and M-CSFR. Oncotarget. 2016;7:80521-80542. doi: 10.18632/oncotarget.11825.

115. Merzak A, McCrea S, Koocheckpour S, Pilkington GJ. Control of human glioma cell growth, migration and invasion in vitro by transforming growth factor beta. Br J Cancer. 1994;70:199-203.

116. Gallo-Oller G, Vollmann-Zwerenz A, Melendez B, Rey JA, Hau P, Dotor J, Castresana JS. P144, a Transforming Growth Factor beta inhibitor peptide, generates antitumoral effects and modifies SMAD7 and SKI levels in human glioblastoma cell lines. Cancer Lett. 2016;381:67-75. doi:10.1016/j.canlet.2016.07.029.

117. Ouanouki A, Lamy S, Annabi B. Anthocyanidins inhibit epithelial-mesenchymal transition through a TGF-beta/ Smad2 signaling pathway in glioblastoma cells. Mol 
Carcinog. 2017;56:1088-1099. doi: 10.1002/mc.22575.

118. Ohshio Y, Teramoto K, Hashimoto M, Kitamura S, Hanaoka J, Kontani K. Inhibition of transforming growth factor- $\beta$ release from tumor cells reduces their motility associated with epithelial-mesenchymal transition. Oncol Rep. 2013;30:1000-6. doi:10.3892/or.2013.2505.

119. Fan QM, Jing YY, Yu GF, Kou XR, Ye F, Gao L, Li R, Zhao QD, Yang Y, Lu ZH, Wei LX. Tumor-associated macrophages promote cancer stem cell-like properties via transforming growth factor-beta1-induced epithelialmesenchymal transition in hepatocellular carcinoma. Cancer Lett. 2014;352:160-8. doi:10.1016/j.canlet.2014.05.008.

120. Salacz ME, Kast RE, Saki N, Brüning A, Karpel-Massler G, Halatsch ME. Toward a noncytotoxic glioblastoma therapy: blocking MCP-1 with the MTZ Regimen. Onco Targets Ther. 2016;9:2535-45. doi: 10.2147/OTT.S100407.

121. Flores-Contreras L, Sandoval-Rodreguez AS, MenaEnriquez MG, Lucano-Landeros S, Arellano-Olivera I, Alvarez-Alvarez A, Sanchez-Parada MG, ArmendarizBorunda J. Treatment with pirfenidone for two years decreases fibrosis, cytokine levels and enhances CB2 gene expression in patients with chronic hepatitis C. BMC Gastroenterol. 2014;14:131. doi: 10.1186/1471-230X-14131.

122. Choi K, Lee K, Ryu SW, Im M, Kook KH, Choi C. Pirfenidone inhibits transforming growth factor-beta1induced fibrogenesis by blocking nuclear translocation of Smads in human retinal pigment epithelial cell line ARPE19. Mol Vis. 2012;18:1010-20.

123. Tian XL, Yao W, Guo ZJ, Gu L, Zhu YJ. Low dose pirfenidone suppresses transforming growth factor beta-1 and tissue inhibitor of metalloproteinase-1, and protects rats from lung fibrosis induced by bleomycin. Chin Med Sci J. 2006;21:145-51.

124. Burghardt I, Tritschler F, Opitz CA, Frank B, Weller M, Wick W. Pirfenidone inhibits TGF-beta expression in malignant glioma cells. Biochem Biophys Res Commun. 2007;354:542-7.

125. Wang H, Shen W, Hu X, Zhang Y, Zhuo Y, Li T, Mei F, Li X, Xiao L, Chu T. Quetiapine inhibits osteoclastogenesis and prevents human breast cancer-induced bone loss through suppression of the RANKL-mediated MAPK and NF-kB signaling pathways. Breast Cancer Res Treat. 2015;149:705-14. doi:10.1007/s10549-015-3290-x.

126. Odero-Marah VA, Wang R, Chu G, Zayzafoon M, Xu J, Shi C, Marshall FF, Zhau HE, Chung LW. Receptor activator of NF-kappaB Ligand (RANKL) expression is associated with epithelial to mesenchymal transition in human prostate cancer cells. Cell Res. 2008;18:858-70. doi: 10.1038/ cr.2008.84.

127. Tsubaki M, Komai M, Fujimoto S, Itoh T, Imano M, Sakamoto K, Shimaoka H, Takeda T, Ogawa N, Mashimo K, Fujiwara D, Mukai J, Sakaguchi K, Satou T, Nishida S. Activation of NF-kB by the RANKL/RANK system upregulates snail and twist expressions and induces epithelial- to-mesenchymal transition in mammary tumor cell lines. J Exp Clin Cancer Res. 2013;32:62. doi:10.1186/1756-996632-62.

128. Gonzalez-Suarez E, Sanz-Moreno A. RANK as a therapeutic target in cancer. FEBS J. 2016;283:2018-33. doi: $10.1111 /$ febs. 13645 .

129. Song FN, Duan M, Liu LZ, Wang ZC, Shi JY, Yang LX, Zhou J, Fan J, Gao Q, Wang XY. RANKL promotes migration and invasion of hepatocellular carcinoma cells via NF-kB mediated epithelial-mesenchymal transition. PLoS One. 2014;9:e108507. doi: 10.1371/journal.pone.0108507.

130. Liu Y, Wang J, Ni T, Wang L, Wang Y, Sun X. CCL20 mediates RANK/RANKL induced epithelial-mesenchymal transition in endometrial cancer cells. Oncotarget. 2016;7:25328-39. doi: 10.18632/oncotarget.8291.

131. Wang J, Liu Y, Wang L, Sun X, Wang Y. Clinical prognostic significance and pro-metastatic activity of RANK/RANKL via the AKT pathway in endometrial cancer. Oncotarget. 2016;7:5564-75. doi: 10.18632/ oncotarget.6795.

132. Yamamoto S, Huang D, Du L, Korn RL, Jamshidi N, Burnette BL, Kuo MD. Radiogenomic Analysis Demonstrates Associations between (18)F-Fluoro-2Deoxyglucose PET, Prognosis, and Epithelial-Mesenchymal Transition in Non-Small Cell Lung Cancer. Radiology. 2016;280:261-70. doi:10.1148/radiol.2016160259.

133. Kim JK, Jin X, Sohn YW, Jin X, Jeon HY, Kim EJ, Ham SW, Jeon HM, Chang SY, Oh SY, Yin J, Kim SH, Park JB, et al. Tumoral RANKL activates astrocytes that promote glioma cell invasion through cytokine signaling. Cancer Lett. 2014;353:194-200. doi: 10.1016/j.canlet.2014.07.034.

134. Vesely JJ, Pien FD, Pien BC. Rifampin, a useful drug for non-mycobacterial infections. Pharmacotherapy. 1998;18:345-57.

135. Bi W, Zhu L, Jing X, Liang Y, Tao E. Rifampicin and Parkinson's disease. Neurol Sci. 2013;34:137-41. doi: 10.1007/s10072-012-1156-0.

136. Yulug B, Hanoglu L, Kilic E, Schabitz WR. RIFAMPICIN: an antibiotic with brain protective function. Brain Res Bull. 2014;107:37-42. doi:10.1016/j.brainresbull.2014.05.007.

137. Valkenburg KC, Graveel CR, Zylstra-Diegel CR, Zhong $Z$, Williams BO. Wnt/ $\beta$-catenin Signaling in Normal and Cancer Stem Cells. Cancers (Basel). 2011;3:2050-79. doi: 10.3390/cancers3022050.

138. Zhan T, Rindtorff N, Boutros M. Wnt signaling in cancer. Oncogene. 2017;36:1461-1473. doi: 10.1038/ onc.2016.304.

139. Lee Y, Lee JK, Ahn SH, Lee J, Nam DH. WNT signaling in glioblastoma and therapeutic opportunities. Lab Invest. 2016;96:137-50. doi:10.1038/labinvest.2015.140.

140. Zhang K, Zhang J, Han L, Pu P, Kang C. Wnt/betacatenin signaling in glioma. J Neuroimmune Pharmacol. 2012;7:740-9. doi: 10.1007/s11481-012-9359-y.

141. Asem MS, Buechler S, Wates RB, Miller DL, Stack MS. 
Wnt5a Signaling in Cancer. Cancers (Basel). 2016;8. doi: 10.3390/cancers8090079.

142. Aberle H, Bauer A, Stappert J, Kispert A, Kemler R. betacatenin is a target for the ubiquitin-proteasome pathway. EMBO J. 1997;16:3797-804.

143. Luo G, Luo W, Sun X, Lin J, Wang M, Zhang Y, Luo W, Zhang Y. MicroRNA-21 promotes migration and invasion of glioma cells via activation of Sox 2 and $\beta$-catenin signaling. Mol Med Rep. 2017;15:187-193. doi: 10.3892/ mmr.2016.5971.

144. Zhang Y, Liu W, He W, Zhang Y, Deng X, Ma Y, Zeng J, Kou B. Tetrandrine reverses epithelial-mesenchymal transition in bladder cancer by downregulating Gli-1. Int J Oncol. 2016;48:2035-42. doi: 10.3892/ijo.2016.3415.

145. Zhang Y, Wen YL, Ma JW, Ye JC, Wang X, Huang JX, Meng CY, Xu XZ, Wang SX, Zhong XY. Tetrandrine inhibits glioma stem-like cells by repressing $\beta$-catenin expression. Int J Oncol. 2017;50:101-110. doi: 10.3892/ ijo.2016.3780.

146. Li J, Huang Y, Gao Y, Wu H, Dong W, Liu L. Antibiotic drug rifabutin is effective against lung cancer cells by targeting the eIF4E-beta-catenin axis. Biochem Biophys Res Commun. 2016;472:299-305. doi:10.1016/j. bbrc.2016.02.120.

147. Wu W, Tian Y, Wan H, Song Y, Li J, Zhang L. The expressions of $\mathrm{Wnt} /$ beta-catenin pathway-related components in brainstem gliomas. Can J Neurol Sci. 2013;40:355-60.

148. Wang K, Wang X, Zou J, Zhang A, Wan Y, Pu P, Song Z, Qian C, Chen Y, Yang S, Wang Y. miR-92b controls glioma proliferation and invasion through regulating Wnt/ beta-catenin signaling via Nemo-like kinase. Neuro Oncol. 2013;15:578-88. doi: 10.1093/neuonc/not004.

149. Zhang K, Zhu S, Liu Y, Dong X, Shi Z, Zhang A, Liu C, Chen L, Wei J, Pu P, Zhang J, Jiang T, Han L, Kang C. ICAT inhibits glioblastoma cell proliferation by suppressing Wnt/beta-catenin activity. Cancer Lett. 2015;357:404-11. doi:10.1016/j.canlet.2014.11.047.

150. Kim KH, Seol HJ, Kim EH, Rheey J, Jin HJ, Lee Y, Joo $\mathrm{KM}$, Lee J, Nam DH. Wnt/beta-catenin signaling is a key downstream mediator of MET signaling in glioblastoma stem cells. Neuro Oncol. 2013;15:161-71. doi: 10.1093/ neuonc/nos299.

151. Yi GZ, Liu YW, Xiang W, Wang H, Chen ZY, Xie SD, Qi ST. Akt and $\beta$-catenin contribute to TMZ resistance and EMT of MGMT negative malignant glioma cell line. J Neurol Sci. 2016;367:101-6. doi: 10.1016/j. jns.2016.05.054.

152. Zhu T, Li X, Luo L, Wang X, Li Z, Xie P, Gao X, Song $\mathrm{Z}$, Su J, Liang G. Reversion of malignant phenotypes of human glioblastoma cells by $\beta$-elemene through $\beta$-cateninmediated regulation of stemness-, differentiation- and epithelial-to-mesenchymal transition-related molecules. J Transl Med. 2015;13:356. doi: 10.1186/s12967-015-0727-
2.

153. Wang Z, Zhang S, Siu TL, Huang S. Glioblastoma multiforme formation and EMT: role of FoxM1 transcription factor. Curr Pharm Des. 2015;21:1268-71.

154. Dong Z, Zhou L, Han N, Zhang M, Lyu X. Wnt/betacatenin pathway involvement in ionizing radiation-induced invasion of U87 glioblastoma cells. Strahlenther Onkol. 2015;191:672-80. doi: 10.1007/s00066-015-0858-7.

155. Yang B, Zhang S, Wang Z, Yang C, Ouyang W, Zhou F, Zhou Y, Xie C. Deubiquitinase USP9X deubiquitinates beta-catenin and promotes high grade glioma cell growth. Oncotarget. 2016;7:79515-79525. doi: 10.18632/ oncotarget.12819.

156. Kahlert UD, Suwala AK, Koch K, Natsumeda M, Orr BA, Hayashi M, Maciaczyk J, Eberhart CG. Pharmacologic Wnt Inhibition Reduces Proliferation, Survival, and Clonogenicity of Glioblastoma Cells. J Neuropathol Exp Neurol. 2015;74:889-900. doi: 10.1097/ NEN.0000000000000227.

157. Sooman L, Ekman S, Andersson C, Kultima HG, Isaksson A, Johansson F, Bergqvist M, Blomquist E, Lennartsson J, Gullbo J. Synergistic interactions between camptothecin and EGFR or RAC1 inhibitors and between imatinib and Notch signaling or RAC1 inhibitors in glioblastoma cell lines. Cancer Chemother Pharmacol. 2013;72:329-40. doi: 10.1007/s00280-013-2197-7.

158. Karpel-Massler G, Westhoff MA, Zhou S, Nonnenmacher L, Dwucet A, Kast RE, Bachem MG, Wirtz CR, Debatin KM, Halatsch ME. Combined inhibition of HER1/EGFR and RAC1 results in a synergistic antiproliferative effect on established and primary cultured human glioblastoma cells. Mol Cancer Ther. 2013;12:1783-95. doi:10.1158/15357163.MCT-13-0052.

159. Gulhati P, Bowen KA, Liu J, Stevens PD, Rychahou PG, Chen M, Lee EY, Weiss HL, O'Connor KL, Gao T, Evers BM. mTORC1 and mTORC2 regulate EMT, motility, and metastasis of colorectal cancer via RhoA and Rac1 signaling pathways. Cancer Res. 2011;71:3246-56. doi: 10.1158/0008-5472.CAN-10-4058.

160. Oprea TI, Sklar LA, Agola JO, Guo Y, Silberberg M, Roxby J, Vestling A, Romero E, Surviladze Z, Murray-Krezan C, Waller A, Ursu O, Hudson LG, Wandinger-Ness A. Novel Activities of Select NSAID R-Enantiomers against Rac1 and Cdc42 GTPases. PLoS One. 2015;10:e142182. doi:10.1371/journal.pone.0142182.

161. Yeung YT, McDonald KL, Grewal T, Munoz L. Interleukins in glioblastoma pathophysiology: implications for therapy. Br J Pharmacol. 2013;168:591-606. doi: 10.1111/bph.12008.

162. Albulescu R, Codrici E, Popescu ID, Mihai S, Necula LG, Petrescu D, Teodoru M, Tanase CP. Cytokine patterns in brain tumour progression. Mediators Inflamm. 2013;2013:979748. doi: 10.1155/2013/979748.

163. Shen F, Zhang Y, Yao Y, Hua W, Zhang HS, Wu JS, 
Zhong P, Zhou LF. Proteomic analysis of cerebrospinal fluid: toward the identification of biomarkers for gliomas. Neurosurg Rev. 2014;37:367-80.

164. Kast RE. Melanoma inhibition by cyclooxygenase inhibitors: role of interleukin-6 suppression, a putative mechanism of action, and clinical implications. Med Oncol. 2007;24:1-6.

165. Kast RE. Tumor necrosis factor has positive and negative self regulatory feed back cycles centered around cAMP. Int J Immunopharmacol. 2000;22:1001-6.

166. Kast RE. Aspirin, TNF-alpha, NFkB, and survival in multiple myeloma: the importance of measuring TNFalpha. Inflammopharmacology. 2006;14:256-9.

167. Shimizu C, Kubo M, Takano K, Takano A, Kijima H, Saji H, Katsuyama I, Sasano H, Koike T. Interleukin-6 (IL-6) producing phaeochromocytoma: direct IL-6 suppression by non-steroidal anti-inflammatory drugs. Clin Endocrinol (Oxf). 2001;54:405-10.

168. Martínez Cairo S, Salgado Legorreta C, Martínez Zurita F. Effect of naproxen on serum concentrations of IL-I, IL-6, and TNF in patients with osteoarthritis. Rev Alerg Mex. 2001;48:119-22.

169. Massicotte F, Lajeunesse D, Benderdour M, Pelletier JP, Hilal G, Duval N, Martel-Pelletier J. Can altered production of interleukin-1beta, interleukin-6, transforming growth factor-beta and prostaglandin $\mathrm{E}(2)$ by isolated human subchondral osteoblasts identify two subgroups of osteoarthritic patients. Osteoarthritis Cartilage. 2002;10:491-500.

170. Pelletier JP, Mineau F, Fernandes J, Kiansa K, Ranger P, Martel-Pelletier J. Two NSAIDs, nimesulide and naproxen, can reduce the synthesis of urokinase and IL-6 while increasing PAI-1, in human OA synovial fibroblasts. Clin Exp Rheumatol. 1997;15:393-8.

171. Sacerdote P, Carrabba M, Galante A, Pisati R, Manfredi B, Panerai AE. Plasma and synovial fluid interleukin-1, interleukin-6 and substance $P$ concentrations in rheumatoid arthritis patients: effect of the nonsteroidal anti inflammatory drugs indomethacin, diclofenac and naproxen. Inflamm Res. 1995;44:486-90.

172. Vaughan CJ, Gallagher M, Murphy MB. Left ventricular myxoma presenting with constitutional symptoms and raised serum interleukin- 6 both suppressed by naproxen. Eur Heart J. 1997;18:703.

173. Liu Q, Li G, Li R, Shen J, He Q, Deng L, Zhang C, Zhang J. IL-6 promotion of glioblastoma cell invasion and angiogenesis in U251 and T98G cell lines. J Neurooncol. 2010;100:165-76. doi: 10.1007/s11060-010-0158-0.

174. Li R, Li G, Deng L, Liu Q, Dai J, Shen J, Zhang J. IL-6 augments the invasiveness of U87MG human glioblastoma multiforme cells via up-regulation of MMP-2 and fascin-1. Oncol Rep. 2010;23:1553-9.

175. Kudo M, Jono H, Shinriki S, Yano S, Nakamura H, Makino K, Hide T, Muta D, Ueda M, Ota K, Ando Y, Kuratsu J.
Antitumor effect of humanized anti-interleukin-6 receptor antibody (tocilizumab) on glioma cell proliferation. Laboratory investigation. J Neurosurg. 2009;111:219-25. doi:10.3171/2008.12.JNS081284.

176. Authier A, Farrand KJ, Broadley KW, Ancelet LR, Hunn MK, Stone S, McConnell MJ, Hermans IF. Enhanced immunosuppression by therapy-exposed glioblastoma multiforme tumor cells. Int J Cancer. 2015;136:2566-78. doi:10.1002/ijc.29309.

177. Stephanou A, Knight RA, Annicchiarico-Petruzzelli M, Finazzi-Agrò A, Lightmann SL, Melino G. Interleukin-1 beta and interleukin-6 mRNA are expressed in human glioblastoma and neuroblastoma cells respectively. Funct Neurol. 1992;7:129-33.

178. Falus A. Interleukin-6 biosynthesis is increased by histamine in human B-cell and glioblastoma cell lines. Immunology. 1993;78:193-6.

179. Lichtor T, Libermann TA. Coexpression of interleukin-1 beta and interleukin-6 in human brain tumors. Neurosurgery. 1994;34:669-72.

180. Ross HJ, Canada AL, Antoniono RJ, Redpath JL. High and low dose rate irradiation have opposing effects on cytokine gene expression in human glioblastoma cell lines. Eur J Cancer. 1997;33:144-52.

181. McFarland BC, Hong SW, Rajbhandari R, Twitty GB Jr, Gray GK, Yu H, Benveniste EN, Nozell SE. NF-кB-induced IL-6 ensures STAT3 activation and tumor aggressiveness in glioblastoma. PLoS One. 2013;8:e78728. doi:10.1371/ journal.pone.0078728.

182. Goswami S, Gupta A, Sharma SK. Interleukin-6-mediated autocrine growth promotion in human glioblastoma multiforme cell line U87MG. J Neurochem. 1998;71:183745.

183. Hotfilder M, Knupfer H, Mohlenkamp G, Pennekamp P, Knupfers M, Van Gool S, Wolff JE. Interferon-gamma increases IL-6 production in human glioblastoma cell lines. Anticancer Res. 2000;20:4445-50.

184. Tchirkov A, Rolhion C, Bertrand S, Doré JF, Dubost JJ, Verrelle P. IL-6 gene amplification and expression in human glioblastomas. Br J Cancer. 2001;85:518-22.

185. Tchirkov A, Khalil T, Chautard E, Mokhtari K, Véronèse L, Irthum B, Vago P, Kémény JL, Verrelle P. Interleukin-6 gene amplification and shortened survival in glioblastoma patients. Br J Cancer. 2007;96:474-6.

186. Sasaki A, Ishiuchi S, Kanda T, Hasegawa M, Nakazato Y. Analysis of interleukin-6 gene expression in primary human gliomas, glioblastoma xenografts, and glioblastoma cell lines. Brain Tumor Pathol. 2001;18:13-21.

187. Chang CY, Li MC, Liao SL, Huang YL, Shen CC, Pan HC. Prognostic and clinical implication of IL-6 expression in glioblastoma multiforme. J Clin Neurosci. 2005;12:930-3.

188. Choi C, Gillespie GY, Van Wagoner NJ, Benveniste EN. Fas engagement increases expression of interleukin-6 in human glioma cells. J Neurooncol. 2002;56:13-9. 
189. Zhang L, Xu Y, Sun J, Chen W, Zhao L, Ma C, Wang Q, Sun J, Huang B, Zhang Y, Li X, Qu X. M2-like tumorassociated macrophages drive vasculogenic mimicry through amplification of IL-6 expression in glioma cells. Oncotarget. 2017;8:819-832. doi: 10.18632/ oncotarget.13661.

190. Samaras V, Piperi C, Levidou G, Zisakis A, Kavantzas N, Themistocleous MS, Boviatsis EI, Barbatis C, Lea RW, Kalofoutis A, Korkolopoulou P. Analysis of interleukin (IL)-8 expression in human astrocytomas: associations with IL-6, cyclooxygenase-2, vascular endothelial growth factor, and microvessel morphometry. Hum Immunol. 2009;70:391-7. doi:10.1016/j.humimm.2009.03.011.

191. Pasi F, Facoetti A, Nano R. IL-8 and IL-6 bystander signalling in human glioblastoma cells exposed to gamma radiation. Anticancer Res. 2010;30:2769-72.

192. Kim SR, Bae MK, Kim JY, Wee HJ, Yoo MA, Bae SK. Aspirin induces apoptosis through the blockade of IL-6STAT3 signaling pathway in human glioblastoma A172 cells. Biochem Biophys Res Commun. 2009;387:342-7. doi:10.1016/j.bbrc.2009.07.022.

193. Wang H, Lathia JD, Wu Q, Wang J, Li Z, Heddleston JM, Eyler CE, Elderbroom J, Gallagher J, Schuschu J, MacSwords J, Cao Y, McLendon RE, et al. Targeting interleukin 6 signaling suppresses glioma stem cell survival and tumor growth. Stem Cells. 2009;27:2393-404. doi: 10.1002/stem.188.

194. Van Meir E, Sawamura Y, Diserens AC, Hamou MF, de Tribolet N. Human glioblastoma cells release interleukin 6 in vivo and in vitro. Cancer Res. 1990;50:6683-8.

195. Muñoz M, García-Vallejo JJ, Sempere JM, Romero R, Olalla E, Sebastián C. Acute phase response in patients undergoing lumbar spinal surgery: modulation by perioperative treatment with naproxen and famotidine. Eur Spine J. 2004;13:367-73.

196. Cohick CB, Furst DE, Quagliata S, Corcoran KA, Steere KJ, Yager JG, Lindsley HB. Analysis of elevated serum interleukin-6 levels in rheumatoid arthritis: correlation with erythrocyte sedimentation rate or C-reactive protein. J Lab Clin Med. 1994;123:721-7.

197. Inda MM, Bonavia R, Mukasa A, Narita Y, Sah DW, Vandenberg S, Brennan C, Johns TG, Bachoo R, Hadwiger P, Tan P, Depinho RA, Cavenee W, Furnari F. Tumor heterogeneity is an active process maintained by a mutant EGFR-induced cytokine circuit in glioblastoma. Genes Dev. 2010;24:1731-45. doi:10.1101/gad.1890510.

198. Karpel-Massler G, Westhoff MA, Kast RE, Wirtz CR, Halatsch ME. Erlotinib in glioblastoma: lost in translation? Anticancer Agents Med Chem. 2011;11:748-55.

199. Pace JR, DeBerardinis AM, Sail V, Tacheva-Grigorova SK, Chan KA, Tran R, Raccuia DS, Wechsler-Reya RJ, Hadden MK. Repurposing the Clinically Efficacious Antifungal Agent Itraconazole as an Anticancer Chemotherapeutic. J Med Chem. 2016;59:3635-49. doi:10.1021/acs. jmedchem.5b01718.
200. Pantziarka P, Sukhatme V, Bouche G, Meheus L, Sukhatme VP. Repurposing Drugs in Oncology (ReDO)-itraconazole as an anti-cancer agent. Ecancermedicalscience. 2015;9:521. doi: 10.3332/ecancer.2015.521.

201. Chandra V, Das T, Gulati P, Biswas NK, Rote S, Chatterjee U, Ghosh SN, Deb S, Saha SK, Chowdhury AK, Ghosh S, Rudin CM, Mukherjee A, et al. Hedgehog signaling pathway is active in GBM with GLI1 mRNA expression showing a single continuous distribution rather than discrete high/low clusters. PLoS One. 2015;10:e0116390. doi:10.1371/journal.pone.0116390.

202. Chang L, Zhang P, Zhao D, Liu H, Wang Q, Li C, Du W, Liu X, Zhang H, Zhang Z, Jiang C. The hedgehog antagonist HHIP as a favorable prognosticator in glioblastoma. Tumour Biol. 2016;37:3979-86. doi:10.1007/ s13277-015-3442-y.

203. Biswas NK, Chandra V, Sarkar-Roy N, Das T, Bhattacharya RN, Tripathy LN, Basu SK, Kumar S, Das S, Chatterjee A, Mukherjee A, Basu P, Maitra A, et al. Variant allele frequency enrichment analysis in vitro reveals sonic hedgehog pathway to impede sustained temozolomide response in GBM. Sci Rep. 2015;5:7915. doi: 10.1038/ srep07915.

204. Munoz JL, Rodriguez-Cruz V, Walker ND, Greco SJ, Rameshwar P. Temozolomide resistance and tumor recurrence: Halting the Hedgehog. Cancer Cell Microenviron. 2015;2.

205. Kim J, Tang JY, Gong R, Kim J, Lee JJ, Clemons KV, Chong CR, Chang KS, Fereshteh M, Gardner D, Reya T, Liu JO, Epstein EH, et al. Itraconazole, a commonly used antifungal that inhibits Hedgehog pathway activity and cancer growth. Cancer Cell. 2010;17:388-99. doi:10.1016/j. ccr.2010.02.027.

206. Santoni M, Burattini L, Nabissi M, Morelli MB, Berardi R, Santoni G, Cascinu S. Essential role of Gli proteins in glioblastoma multiforme. Curr Protein Pept Sci. 2013;14:133-40.

207. Shahi MH, Zazpe I, Afzal M, Sinha S, Rebhun RB, Meléndez B, Rey JA, Castresana JS. Epigenetic regulation of human hedgehog interacting protein in glioma cell lines and primary tumor samples. Tumour Biol. 2015;36:238391. doi: 10.1007/s13277-014-2846-4.

208. Wang K, Pan L, Che X, Cui D, Li C. Gli1 inhibition induces cell-cycle arrest and enhanced apoptosis in brain glioma cell lines. J Neurooncol. 2010;98:319-27. doi:10.1007/s11060009-0082-3.

209. Wang X, Wei S, Zhao Y, Shi C, Liu P, Zhang C, Lei Y, Zhang B, Bai B, Huang Y, Zhang H. Anti-proliferation of breast cancer cells with itraconazole: Hedgehog pathway inhibition induces apoptosis and autophagic cell death. Cancer Lett. 2017;385:128-136. doi:10.1016/j. canlet.2016.10.034.

210. Liang G, Liu M, Wang Q, Shen Y, Mei H, Li D, Liu W. Itraconazole exerts its anti-melanoma effect by suppressing Hedgehog, Wnt, and PI3K/mTOR signaling pathways. 
Oncotarget. 2017; 8:28510-28525. doi: 10.18632/ oncotarget. 15324.

211. Tsubamoto H, Inoue K, Sakata K, Ueda T, Takeyama R, Shibahara H, Sonoda T. Itraconazole Inhibits AKT/mTOR Signaling and Proliferation in Endometrial Cancer Cells. Anticancer Res. 2017;37:515-519.

212.Marin-Penalver JJ, Martin-Timon I, Sevillano-Collantes C, Del Canizo-Gomez FJ. Update on the treatment of type 2 diabetes mellitus. World J Diabetes. 2016;7:354-95. doi: 10.4239/wjd.v7.i17.354

213.Barriere G, Tartary M, Rigaud M. Metformin: a rising star to fight the epithelial mesenchymal transition in oncology. Anticancer Agents Med Chem. 2013;13:333-40.

214. Del Barco S, Vazquez-Martin A, Cufi S, Oliveras-Ferraros C, Bosch-Barrera J, Joven J, Martin-Castillo B, Menendez JA. Metformin: multi-faceted protection against cancer. Oncotarget. 2011;2:896-917. doi: 10.18632/oncotarget.387.

215. Chae YK, Arya A, Malecek MK, Shin DS, Carneiro B, Chandra S, Kaplan J, Kalyan A, Altman JK, Platanias L, Giles F. Repurposing metformin for cancer treatment: current clinical studies. Oncotarget. 2016;7:40767-40780. doi:10.18632/oncotarget.8194.

216. Xu H, Aldrich MC, Chen Q, Liu H, Peterson NB, Dai Q, Levy M, Shah A, Han X, Ruan X, Jiang M, Li Y, Julien JS, Warner J, et al. Validating drug repurposing signals using electronic health records: a case study of metformin associated with reduced cancer mortality. J Am Med Inform Assoc. 2015;22:179-91. doi: 10.1136/amiajnl-2014-002649.

217. Peng M, Darko KO, Tao T, Huang Y, Su Q, He C, Yin $\mathrm{T}$, Liu Z, Yang X. Combination of metformin with chemotherapeutic drugs via different molecular mechanisms. Cancer Treat Rev. 2017;54:24-33. doi:10.1016/j.ctrv.2017.01.005.

218. Liu X, Romero IL, Litchfield LM, Lengyel E, Locasale JW. Metformin Targets Central Carbon Metabolism and Reveals Mitochondrial Requirements in Human Cancers. Cell Metab. 2016;24:728-739. doi: 10.1016/j.cmet.2016.09.005.

219. Mihaylova MM, Shaw RJ. The AMPK signalling pathway coordinates cell growth, autophagy and metabolism. Nat Cell Biol. 2011;13:1016-23. doi:10.1038/ncb232

220. Carmignani M, Volpe AR, Aldea M, Soritau O, Irimie A, Florian IS, Tomuleasa C, Baritchii A, Petrushev B, Crisan G, Valle G. Glioblastoma stem cells: a new target for metformin and arsenic trioxide. J Biol Regul Homeost Agents. 2014;28:1-15.

221. Sato A, Sunayama J, Okada M, Watanabe E, Seino S, Shibuya K, Suzuki K, Narita Y, Shibui S, Kayama T, Kitanaka C. Glioma-initiating cell elimination by metformin activation of FOXO3 via AMPK. Stem Cells Transl Med. 2012;1:811-24. doi: 10.5966/sctm.2012-0058.

222. Liu Z, Qi S, Zhao X, Li M, Ding S, Lu J, Zhang H. Metformin inhibits 17beta-estradiol induced epithelialto-mesenchymal transition via betaKlotho-related ERK1/2 signaling and AMPK signaling in endometrial adenocarcinoma cells. Oncotarget. 2016;7:21315-31. doi: 10.18632/oncotarget.7040.

223. Koeck S, Amann A, Huber JM, Gamerith G, Hilbe W, Zwierzina $H$. The impact of metformin and salinomycin on transforming growth factor beta-induced epithelial-tomesenchymal transition in non-small cell lung cancer cell lines. Oncol Lett. 2016;1:2946-2952.

224. Zhang J, Shen C, Wang L, Ma Q, Xia P, Qi M, Yang M, Han B. Metformin inhibits epithelial-mesenchymal transition in prostate cancer cells: involvement of the tumor suppressor miR30a and its target gene SOX4. Biochem Biophys Res Commun. 2014;452:746-52. doi: 10.1016/j. bbrc.2014.08.154.

225. Ge R, Wang Z, Wu S, Zhuo Y, Otsetov AG, Cai C, Zhong $\mathrm{W}, \mathrm{Wu} \mathrm{CL}$, Olumi AF. Metformin represses cancer cells via alternate pathways in $\mathrm{N}$-cadherin expressing vs. $\mathrm{N}$-cadherin deficient cells. Oncotarget. 2015;6:28973-87. doi:10.18632/ oncotarget.5023.

226. Cheng K, Hao M. Metformin Inhibits TGF- $\beta 1$-Induced Epithelial-to-Mesenchymal Transition via PKM2 RelativemTOR/p70s6k Signaling Pathway in Cervical Carcinoma Cells. Int J Mol Sci. 2016;17.

227. Laskov I, Abou-Nader P, Amin O, Philip CA, Beauchamp MC, Yasmeen A, Gotlieb WH. Metformin Increases E-cadherin in Tumors of Diabetic Patients With Endometrial Cancer and Suppresses Epithelial-Mesenchymal Transition in Endometrial Cancer Cell Lines. Int J Gynecol Cancer. 2016;26:1213-21. doi:10.1097/IGC.0000000000000761.

228. Nakayama A, Ninomiya I, Harada S, Tsukada T, Okamoto K, Nakanuma S, Sakai S, Makino I, Kinoshita J, Hayashi H, Oyama K, Miyashita T, Tajima H, et al. Metformin inhibits the radiation-induced invasive phenotype of esophageal squamous cell carcinoma. Int J Oncol. 2016;49:1890-1898. doi: 10.3892/ijo.2016.3676.

229. Ippolito L, Marini A, Cavallini L, Morandi A, Pietrovito L, Pintus G, Giannoni E, Schrader T, Puhr M, Chiarugi P, Taddei ML. Metabolic shift toward oxidative phosphorylation in docetaxel resistant prostate cancer cells. Oncotarget. 2016;7:61890-61904. doi:10.18632/ oncotarget.11301.

230. Kurimoto R, Iwasawa S, Ebata T, Ishiwata T, Sekine I, Tada Y, Tatsumi K, Koide S, Iwama A, Takiguchi Y. Drug resistance originating from a TGF-beta/ FGF-2-driven epithelial-to-mesenchymal transition and its reversion in human lung adenocarcinoma cell lines harboring an EGFR mutation. Int J Oncol. 2016;48:1825-36. doi: 10.3892/ ijo.2016.3419.

231. Jun KH, Lee JE, Kim SH, Jung JH, Choi HJ, Kim YI, Chin HM, Yang SH. Clinicopathological significance of $\mathrm{N}$-cadherin and VEGF in advanced gastric cancer brain metastasis and the effects of metformin in preclinical models. Oncol Rep. 2015;34:2047-53. doi: 10.3892/ or.2015.4191.

232. Peppicelli S, Toti A, Giannoni E, Bianchini F, Margheri F, Del Rosso M, Calorini L. Metformin is also effective 
on lactic acidosis-exposed melanoma cells switched to oxidative phosphorylation. Cell Cycle. 2016;15:1908-18. doi:10.1080/15384101.2016.1191706.

233. You A, Cao M, Guo Z, Zuo B, Gao J, Zhou H, Li H, Cui Y, Fang F, Zhang W, Song T, Li Q, Zhu X, et al. Metformin sensitizes sorafenib to inhibit postoperative recurrence and metastasis of hepatocellular carcinoma in orthotopic mouse models. J Hematol Oncol. 2016;9:20. doi:10.1186/s13045016-0253-6.

234. Wahdan-Alaswad R, Harrell JC, Fan Z, Edgerton SM, Liu B, Thor AD. Metformin attenuates transforming growth factor beta (TGFbeta) mediated oncogenesis in mesenchymal stem-like/claudin-low triple negative breast cancer. Cell Cycle. 2016;15:1046-59. doi: 10.1080/15384101.2016.1152432.

235. Han B, Cui H, Kang L, Zhang X, Jin Z, Lu L, Fan Z. Metformin inhibits thyroid cancer cell growth, migration, and EMT through the mTOR pathway. Tumour Biol. 2015;36:6295-304. doi: 10.1007/s13277-015-3315-4.

236. Zhao Z, Cheng X, Wang Y, Han R, Li L, Xiang T, He L, Long H, Zhu B, He Y. Metformin inhibits the IL-6-induced epithelial-mesenchymal transition and lung adenocarcinoma growth and metastasis. PLoS One. 2014;9:e95884. doi:10.1371/journal.pone.0095884.

237. Giannoni E, Taddei ML, Morandi A, Comito G, Calvani M, Bianchini F, Richichi B, Raugei G, Wong N, Tang D, Chiarugi P. Targeting stromal-induced pyruvate kinase M2 nuclear translocation impairs oxphos and prostate cancer metastatic spread. Oncotarget. 2015;6:24061-74. doi: 10.18632/oncotarget.4448.

238. Li L, Han R, Xiao H, Lin C, Wang Y, Liu H, Li K, Chen H, Sun F, Yang Z, Jiang J, He Y. Metformin sensitizes EGFRTKI-resistant human lung cancer cells in vitro and in vivo through inhibition of IL-6 signaling and EMT reversal. Clin Cancer Res. 2014;20:2714-26. doi: 10.1158/1078-0432. CCR-13-2613.

239. Qu C, Zhang W, Zheng G, Zhang Z, Yin J, He Z. Metformin reverses multidrug resistance and epithelial-mesenchymal transition (EMT) via activating AMP-activated protein kinase (AMPK) in human breast cancer cells. Mol Cell Biochem. 2014;386:63-71. doi: 10.1007/s11010-0131845-x.

240. Chou CC, Lee KH, Lai IL, Wang D, Mo X, Kulp SK, Shapiro CL, Chen CS. AMPK reverses the mesenchymal phenotype of cancer cells by targeting the Akt-MDM2Foxo3a signaling axis. Cancer Res. 2014;74:4783-95. doi:10.1158/0008-5472.CAN-14-0135.

241. Liang G, Ding M, Lu H, Cao NA, Niu Y, Gao Y, Lu J. Metformin upregulates E-cadherin and inhibits B16F10 cell motility, invasion and migration. Oncol Lett. 2015;10:15271532.

242. Wang M, Weng X, Guo J, Chen Z, Jiang G, Liu X. Metformin alleviated EMT and fibrosis after renal ischemiareperfusion injury in rats. Ren Fail. 2016;38:614-21. doi: 10.3109/0886022X.2016.1149770.
243. Thakur S, Viswanadhapalli S, Kopp JB, Shi Q, Barnes JL, Block K, Gorin Y, Abboud HE. Activation of AMPactivated protein kinase prevents TGFbeta induced epithelial-mesenchymal transition and myofibroblast activation. Am J Pathol. 2015;185:2168-80. doi: 10.1016/j. ajpath.2015.04.014.

244. Lin H, Li N, He H, Ying Y, Sunkara S, Luo L, Lv N, Huang D, Luo Z. AMPK Inhibits the Stimulatory Effects of TGFbeta on Smad2/3 Activity, Cell Migration, and Epithelial-toMesenchymal Transition. Mol Pharmacol. 2015;88:106271. doi: 10.1124/mol.115.099549.

245. Li NS, Zou JR, Lin H, Ke R, He XL, Xiao L, Huang D, Luo L, Lv N, Luo Z. LKB1/AMPK inhibits TGF- $\beta 1$ production and the TGF- $\beta$ signaling pathway in breast cancer cells. Tumour Biol. 2016;37:8249-58. doi:10.1007/s13277-0154639-9.

246. Wang Y, Yao B, Wang Y, Zhang M, Fu S, Gao H, Peng $\mathrm{R}$, Zhang L, Tang J. Increased FoxM1 expression is a target for metformin in the suppression of EMT in prostate cancer. Int J Mol Med. 2014;33:1514-22. doi:10.3892/ ijmm.2014.1707.

247. Petrushev B, Tomuleasa C, Soritau O, Aldea M, Pop T, Susman S, Kacso G, Berindan I, Irimie A, Cristea V. Metformin plus PIAF combination chemotherapy for hepatocellular carcinoma. Exp Oncol. 2012;34:17-24.

248. Aldea MD, Petrushev B, Soritau O, Tomuleasa CI, Berindan-Neagoe I, Filip AG, Chereches G, Cenariu M, Craciun L, Tatomir C, Florian IS, Crivii CB, Kacso G. Metformin plus sorafenib highly impacts temozolomide resistant glioblastoma stem-like cells. J BUON. 2014;19:502-11.

249. Soritau O, Tomuleasa C, Aldea M, Petrushev B, Susman S, Gheban D, Ioani H, Cosis A, Brie I, Irimie A, Kacso G, Florian IS. Metformin plus temozolomide-based chemotherapy as adjuvant treatment for WHO grade III and IV malignant gliomas. J BUON. 2011;16:282-9.

250. Yu Z, Zhao G, Li P, Li Y, Zhou G, Chen Y, Xie G. Temozolomide in combination with metformin act synergistically to inhibit proliferation and expansion of glioma stem-like cells. Oncol Lett. 2016;11:2792-2800.

251. Carmignani M, Volpe AR, Aldea M, Soritau O, Irimie A, Florian IS, Tomuleasa C, Baritchii A, Petrushev B, Crisan G, Valle G. Glioblastoma stem cells: a new target for metformin and arsenic trioxide. J Biol Regul Homeost Agents. 2014;28:1-15.

252. Seliger C, Meyer AL, Renner K, Leidgens V, Moeckel S, Jachnik B, Dettmer K, Tischler U, Gerthofer V, Rauer L, Uhl M, Proescholdt M, Bogdahn U, et al. Metformin inhibits proliferation and migration of glioblastoma cells independently of TGF-beta. Cell Cycle. 2016;15:1755-66. doi:10.1080/15384101.2016.1186316.

253. Sesen J, Dahan P, Scotland SJ, Saland E, Dang VT, Lemarié A, Tyler BM, Brem H, Toulas C, Cohen-Jonathan Moyal E, Sarry JE, Skuli N. Metformin inhibits growth of human glioblastoma cells and enhances therapeutic response. 
PLoS One. 2015;10:e0123721. doi: 10.1371/journal. pone. 0123721 .

254. Yang SH, Li S, Lu G, Xue H, Kim DH, Zhu JJ, Liu Y. Metformin treatment reduces temozolomide resistance of glioblastoma cells. Oncotarget. 2016;7:78787-78803. doi: 10.18632/oncotarget.12859.

255. Leidgens V, Proske J, Rauer L, Moeckel S, Renner K, Bogdahn U, Riemenschneider MJ, Proescholdt M, Vollmann-Zwerenz A, Hau P, Seliger C. Stattic and metformin inhibit brain tumor initiating cells by reducing STAT3-phosphorylation. Oncotarget. 2017;8:8250-8263. doi: 10.18632/oncotarget.14159.

256. Łabuzek K, Suchy D, Gabryel B, Bielecka A, Liber S, Okopień B. Quantification of metformin by the HPLC method in brain regions, cerebrospinal fluid and plasma of rats treated with lipopolysaccharide. Pharmacol Rep. 2010;62:956-65.

257. Lalau JD, Lemaire-Hurtel AS, Lacroix C. Establishment of a database of metformin plasma concentrations and erythrocyte levels in normal and emergency situations. Clin Drug Investig. 2011;31:435-8. doi:10.2165/11588310000000000-00000.

258. Zhao B, Wang X, Zheng J, Wang H, Liu J. Effects of metformin treatment on glioma induced brain edema. Am J Transl Res. 2016;8:3351-63.

259. King TE Jr, Bradford WZ, Castro-Bernardini S, Fagan EA, Glaspole I, Glassberg MK, Gorina E, Hopkins PM, Kardatzke D, Lancaster L, Lederer DJ, Nathan $\mathrm{SD}$, Pereira CA, et al. A phase 3 trial of pirfenidone in patients with idiopathic pulmonary fibrosis. N Engl J Med. 2014;370:2083-92. doi: 10.1056/NEJMoa1402582.

260. Kasper S, Tauscher J, Heiden A. Quetiapine: efficacy and tolerability in schizophrenia. Eur Neuropsychopharmacol. 2001;11:S405-13.
261. Brumfitt W, Hamilton-Miller JM. Rifampicin in non-tuberculous infections. Br Med J (Clin Res Ed). 1984;289:496.

262. Rae JM, Johnson MD, Lippman ME, Flockhart DA. Rifampin is a selective, pleiotropic inducer of drug metabolism genes in human hepatocytes: studies with cDNA and oligonucleotide expression arrays. J Pharmacol Exp Ther. 2001;299:849-57.

263. Angiolillo DJ, Weisman SM. Clinical Pharmacology and Cardiovascular Safety of Naproxen. Am J Cardiovasc Drugs. 2017;17:97-107. doi: 10.1007/s40256-016-0200-5.

264. Lestner J, Hope WW. Itraconazole: an update on pharmacology and clinical use for treatment of invasive and allergic fungal infections. Expert Opin Drug Metab Toxicol. 2013;9:911-26. doi: 10.1517/17425255.2013.794785.

265. Johnson M, Krosnick A, Carson P, McDade AM, Laraway K. A retrospective chart review of uncontrolled use of metformin as an add-on therapy in type 2 diabetes. Clin Ther. 1998;20:691-8.

266. Frosina G. Development of therapeutics for high grade gliomas using orthotopic rodent models. Curr Med Chem. 2013;20:3272-3299. 